\title{
Heparan Sulfate Proteoglycans in Viral Infection and Treatment: A Special Focus on SARS-CoV-2
}

\author{
Valeria De Pasquale ${ }^{1, *}$, , Miriam Shasa Quiccione ${ }^{2}$, Simona Tafuri ${ }^{1}$, Luigi Avallone ${ }^{1}$ \\ and Luigi Michele Pavone ${ }^{2, *(D)}$ \\ 1 Department of Veterinary Medicine and Animal Productions, University of Naples Federico II, \\ 80137 Naples, Italy; stafuri@unina.it (S.T.); avallone@unina.it (L.A.) \\ 2 Department of Molecular Medicine and Medical Biotechnology, Medical School, \\ University of Naples Federico II, 80131 Naples, Italy; m.quiccione@studenti.unina.it \\ * Correspondence: valeria.depasquale@unina.it (V.D.P.); luigimichele.pavone@unina.it (L.M.P.)
}

check for

updates

Citation: De Pasquale, V.; Quiccione, M.S.; Tafuri, S.; Avallone, L.; Pavone, L.M. Heparan Sulfate Proteoglycans in Viral Infection and Treatment: A Special Focus on SARS-CoV-2. Int. J. Mol. Sci. 2021, 22, 6574. https:// doi.org/10.3390/ijms22126574

Academic Editors: Chiara Schiraldi, Donatella Cimini and Annalisa La Gatta

Received: 26 May 2021

Accepted: 16 June 2021

Published: 18 June 2021

Publisher's Note: MDPI stays neutral with regard to jurisdictional claims in published maps and institutional affiliations.

Copyright: (c) 2021 by the authors. Licensee MDPI, Basel, Switzerland. This article is an open access article distributed under the terms and conditions of the Creative Commons Attribution (CC BY) license (https:// creativecommons.org/licenses/by/ $4.0 /)$.

\begin{abstract}
Heparan sulfate proteoglycans (HSPGs) encompass a group of glycoproteins composed of unbranched negatively charged heparan sulfate (HS) chains covalently attached to a core protein. The complex HSPG biosynthetic machinery generates an extraordinary structural variety of HS chains that enable them to bind a plethora of ligands, including growth factors, morphogens, cytokines, chemokines, enzymes, matrix proteins, and bacterial and viral pathogens. These interactions translate into key regulatory activity of HSPGs on a wide range of cellular processes such as receptor activation and signaling, cytoskeleton assembly, extracellular matrix remodeling, endocytosis, cell-cell crosstalk, and others. Due to their ubiquitous expression within tissues and their large functional repertoire, HSPGs are involved in many physiopathological processes; thus, they have emerged as valuable targets for the therapy of many human diseases. Among their functions, HSPGs assist many viruses in invading host cells at various steps of their life cycle. Viruses utilize HSPGs for the attachment to the host cell, internalization, intracellular trafficking, egress, and spread. Recently, HSPG involvement in the pathogenesis of SARS-CoV-2 infection has been established. Here, we summarize the current knowledge on the molecular mechanisms underlying HSPG/SARS-CoV-2 interaction and downstream effects, and we provide an overview of the HSPG-based therapeutic strategies that could be used to combat such a fearsome virus.
\end{abstract}

Keywords: heparan sulfate proteoglycans; virus; SARS-CoV-2; pathogenesis; therapy

\section{Heparan Sulfate Proteoglycans: Structure, Biosynthesis, Processing, and Functions}

Proteoglycans (PGs) consist of a core protein bearing one or more carbohydrate chain of glycosaminoglycans (GAGs) [1,2]. Although structurally complex, GAG polysaccharides are simply made up of repeating disaccharide units composed of an amino sugar and one uronic acid. The uronic acid unit may be either $\beta$-d-glucuronic acid (GlcA) or its C5 epimerized form, $\alpha$-1-iduronic acid (IdoA), whereas the amino sugar may consist of either glucose (Glc)-based ( $\alpha$-d- or $\beta$-d-glucosamine, GlcN) or galactose (Gal)-based amino sugars such as $N$-acetyl- $\beta$-d-galactosamine (GalNAc). Based on their composition, GAGs are classified as chondroitin sulfate (CS), dermatan sulfate (DS), heparin and heparan sulfate (HS), keratan sulfate (KS), and the non-sulfated hyaluronic acid (HA). In the heparan sulfate proteoglycans (HSPGs), the core protein is covalently attached to long linear HS chains composed of alternating GlcA and $\alpha-\mathrm{GlcN}$ disaccharide units that can be variably $N$ - and $O$-sulfated (Figure 1 ).

HSPG synthesis, occurring in the Golgi apparatus upon the arrival of the core protein from the endoplasmic reticulum, starts with the attachment of a tetra-saccharide linker (xylose-galactose-galactose-glucuronic acid) to a serine residue of the core protein and proceeds with the elongation of the polysaccharide backbone by the addition of GlcNAc and GlcA mediated by exostosin glycosyltransferases (EXT1/2; EXTL1/2/3). Next, the 
$\mathrm{N}$-acetyl group of GlcNAc is removed and replaced by a sulfate group through the action of $\mathrm{N}$-deacetylase/N-sulfotransferases (NDST1/2/3/4). The glucuronyl C5-epimerase (GLCE) promotes the epimerization of GlcA to IdoA, followed by O-sulfotransferase (OST) activity triggering the 2-O-sulfation and 3-O-sulfation of IdoA and $\mathrm{GlcN}$, respectively, and the 6-Osulfation of $\mathrm{N}$-acetylated or $\mathrm{N}$-sulfated $\mathrm{GlcN}$ residues (Figure 1). The reactions mediated by the Golgi-localized enzymes likely engage only some fraction of potentially available sugar units, giving rise to highly heterogeneous HS chains [3].

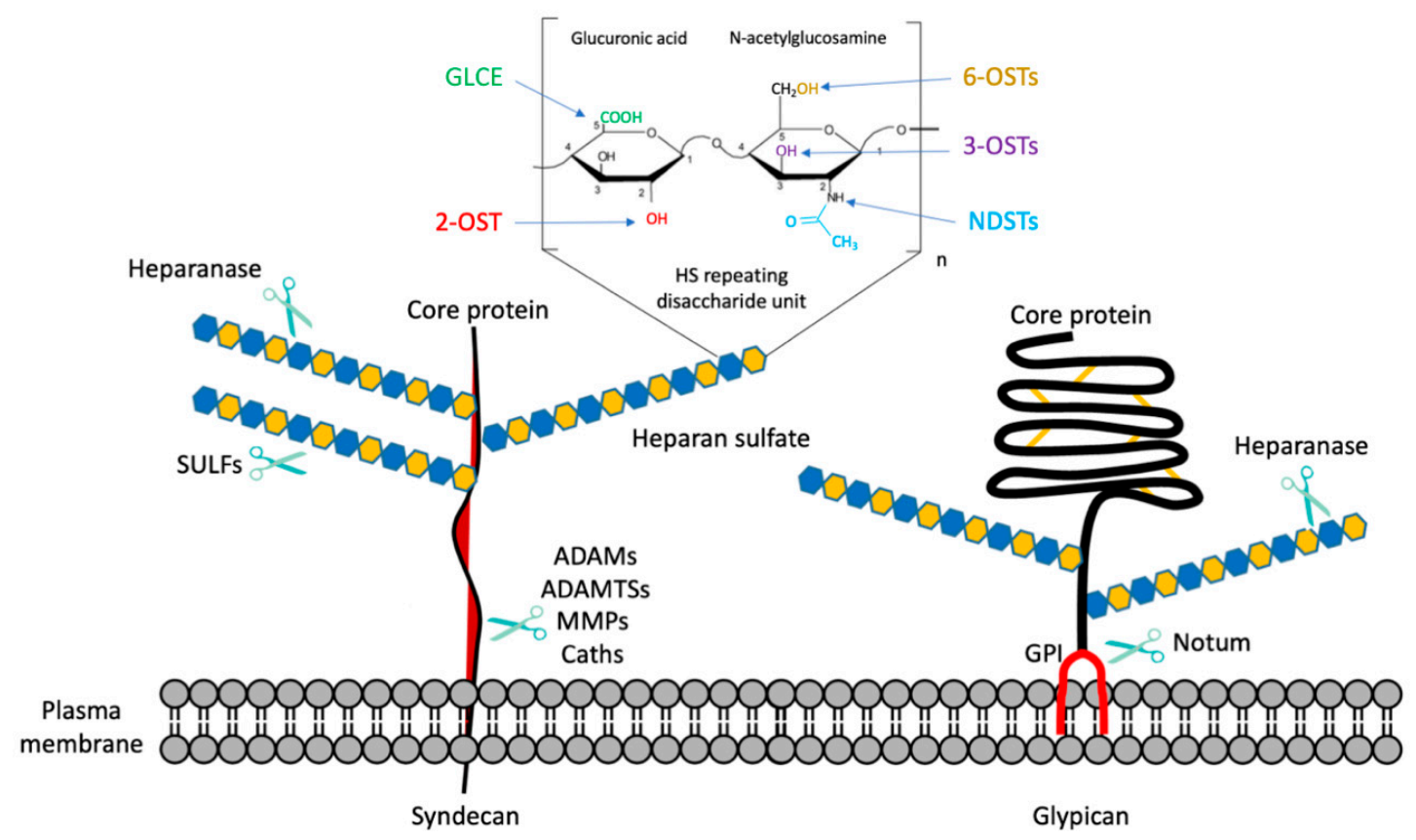

Figure 1. Schematic depiction of the repeating disaccharide unit in HS chains, the sites of action of biosynthetic and post-translational enzymes, and syndecan and glypican structures. NDSTs, N-deacetylase/N-sulfotransferases; GLCE, glucuronyl C5-epimerase; OSTs, O-sulfotransferases; MMPs, matrix metalloproteinases; ADAMs, a disintegrin and metalloproteinases; ADAMTSs, ADAMs with a thrombospondin motif; Caths, cathepsins; SULFs, extracellular sulfatases; GPI, glycosylphosphatidylinositol.

Once synthesized and exported to their localization on the cell surface and extracellular matrix (ECM), HSPGs may undergo further modifications through the action of enzymes that target either HSPG protein core or HS chains [4]. These enzymes include sheddases, the endoglycosidase heparanase, and 6-O-endosulfatases (Figure 1). The first type of HSPG-modifying enzymes, generically termed sheddases, target the core protein of cell surface HSPGs, triggering the release of their HS-bearing ectodomain into the extracellular milieu. The sheddases include the extracellular lipase Notum, and proteases such as matrix metalloproteinases (MMPs); ADAMs, a disintegrin and metalloproteinases; ADAMTSs, which are ADAMs with a thrombospondin motif; and cathepsins [5]. Heparanase is an endoglucuronidase that specifically cleaves HS chains, acting on the GlcA-GlcNS glycosidic bond $[4,6]$. As a result of the heparanase activity, shorter HS fragments are released that may either promote ECM remodeling or activate HSPG catabolism [4,7]. Extracellular endosulfatases (SULF1/2) promote 6-O-desulfation of HS, starting from the non-reducing end of HS chain S-domains, with a strong preference for the [Glc/IdoA(2S)-GlcNS(6S)] trisulfated disaccharides, which are mostly present within HS functional S-domains $[4,8]$. Hence, SULF activity has a great impact on HS binding properties and functions. The post-synthetic modifications occurring in the HSPG structure at the cell surface and ECM are cell- and tissue-specific and augment the structural heterogeneity and complexity of HSPGs, features that account for their wide range of functions [4,9].

The main classes of HSPGs include: (a) cell-surface-localized syndecans, characterized by an extracellular domain harboring HS chains, a single transmembrane domain, and a 
short C-terminal cytoplasmic domain; (b) glypicans, attached to the cell membrane via a glycosylphosphatidylinositol (GPI) anchor, bearing HS chains near the juxtamembrane region (Figure 1); (c) perlecan, agrin, and collagen type XVIII localized at the ECM, including the basement membrane zone; and (d) the intracellular proteoglycan serglycin, which may vary in its GAG composition depending on the cell type.

Ubiquitously expressed on the cell surface and ECM of all cell types, HSPGs regulate numerous signaling pathways involved in developmental and physiopathological processes [10-17]. Beside an important structural role, HSPGs - through either their negatively charged sulfated moieties of HS chains or the protein cores-interact with a variety of ligands regulating their distribution, availability, and signaling activity. Hence, HSPGs play fundamental roles in cell proliferation, differentiation, adhesion, migration, survival, autophagy, inflammation, immune defense, and many other cellular processes [11-20]. HSPGs serve as co-receptors for morphogens and growth factors, allowing a proper presentation to their cognate receptors, either in cis (on the same cell) or in trans (on adjacent cells), thus facilitating receptor activation and downstream signaling $[1-4,9,14,15,18-20]$. In some cases, HSPGs may also act as receptors themselves [1-3,9,10,18-20]. In addition, HSPGs play a crucial role in endocytosis and vesicular trafficking, thus regulating the movement of molecules between intracellular and extracellular compartments [1,2,21-23]. In particular, HSPGs promote the internalization of a variety of macromolecules such as cationic polymers, liposomes, DNA, RNases, cancer cell exosomes, cell-penetrating peptides, protein aggregates, and pathogens [1-3,9,10,21-24]. Among pathogens, many viruses hijack HSPGs to enter and to infect host cells, although with different mechanisms [24,25].

\section{Molecular Mechanisms by Which Viruses Exploit Heparan Sulfate Proteoglycans to Infect Host Cells}

Some viruses take advantage of the electrostatic interactions between the negatively charged sulfated HS chains and the basic residues of their surface or capsid proteins to increase their concentration at the host cell surface, thus enhancing their binding to specific entry receptors [24,25]. Table 1 lists the viruses whose infection in the human organism is strictly dependent on their ability to bind the cell surface HSPGs [26-69].

The interaction of the viral gp120 envelope protein with HS, prior to CD4 receptor recognition, increases the infectivity of the human immunodeficiency virus (HIV) by preconcentrating the virion particles at the cell surface [37-39]. Hepatitis C virus (HCV) hijacks apolipoprotein $\mathrm{E}$ (apoE) to interact with HS structures, prior to sequential interactions with cellular entry factors such as the scavenger receptor SRB1, the tetraspanin CD81, and two tight junction proteins, claudin- 1 and occluding [44-47]. In particular, syndecan- 1 and syndecan-4 serve as major cellular factors for HCV attachment to hepatocytes $[45,46]$. The binding of the major capsid protein, pORF2, to the HSPGs, specifically syndecans, leads to hepatitis $E$ virus (HEV) enrichment on the cell surface, allowing subsequent interaction with entry receptors $[49,50]$. The respiratory pathogen human metapneumovirus (HMPV) uses HSPGs to bind to target cells and undergoes clathrin-mediated endocytosis and membrane fusion in endosomes. The binding of the HMPV fusion protein F with cell surface HSPGs is mandatory for infection $[57,58]$. The cell surface HS functions as the first attachment host factor for rabies virus (RABV) through its binding to the viral glycoprotein $(G)$, thus supporting subsequent viral interaction with entry receptors including the nicotinic acetylcholine receptor, the neuronal cell adhesion molecule (NCAM), and the nerve growth factor receptor p75NTR $[59,61]$. 
Table 1. Viral and host factors involved in the attachment and entry of human viruses.

\begin{tabular}{|c|c|c|c|}
\hline Virus & Viral Factors & Host Cell Surface Factors & Reference(s) \\
\hline $\begin{array}{l}\text { Coronavirus NL63 } \\
\text { (HCoV-NL63) }\end{array}$ & $\begin{array}{l}\text { Envelope glycoprotein }(\mathrm{gpE}), \\
\text { and membrane protein }(\mathrm{M})\end{array}$ & $\begin{array}{l}\text { Angiotensin-converting enzyme } 2 \text { (ACE2) receptor, } \\
\text { HSPGs }\end{array}$ & [26-28] \\
\hline $\begin{array}{l}\text { Dengue Virus } \\
\quad(\mathrm{DENV})\end{array}$ & $\begin{array}{l}\text { Capsid protein }(\mathrm{C}), \text { membrane } \\
\text { protein }(\mathrm{prM} / \mathrm{M}) \text { and } \\
\text { envelope protein }(\mathrm{E})\end{array}$ & $\begin{array}{c}\text { HSPGs, integrin } \alpha 3 \text {, adhesion molecule-3-grabbing } \\
\text { non-integrin (DC-SIGN) }\end{array}$ & [29-31] \\
\hline $\begin{array}{l}\text { Enterovirus A71 } \\
\qquad(\mathrm{EV}-\mathrm{A} 71)\end{array}$ & Capsid VP1-4 proteins & $\begin{array}{c}\text { P-selectin glycoprotein ligand-1, annexin II, } \\
\text { vimentin, HSPGs, sialylated glycans, fibronectin, } \\
\text { prohibitin, cyclophilin A, scavenger receptor class B } \\
\text { member } 2 \text { (SCARB2) }\end{array}$ & [32] \\
\hline $\begin{array}{l}\text { Herpes Simplex Virus } \\
\text { types } 1 \text { and } 2 \\
\text { (HSV-1 and -2) }\end{array}$ & $\begin{array}{l}\text { Envelope glycoproteins gB, } \\
\mathrm{gC}, \mathrm{gD}, \mathrm{gE}, \mathrm{gG}, \mathrm{gH}, \mathrm{gI}, \mathrm{gJ}, \mathrm{gK}, \\
\mathrm{gL}, \mathrm{gM} \text {, and gN }\end{array}$ & $\begin{array}{l}\text { Syndecan- } 1 \text { and }-2 \text {, nectin-1, complement } \\
\text { component } C 3 b, \alpha v \beta 6 \text { - and } \alpha v \beta 8 \text {-integrins }\end{array}$ & [33-36] \\
\hline $\begin{array}{l}\text { Human } \\
\text { Immunodeficiency } \\
\text { Virus } \\
\text { (HIV) }\end{array}$ & Glycoprotein gp120 & $\begin{array}{l}\text { Trans-activator transcription (Tat) protein, CD4 } \\
\text { receptor and coreceptor (e.g., chemokine receptor } \\
\text { CCR5 or CXCR4), syndecans }\end{array}$ & [37-39] \\
\hline $\begin{array}{l}\text { Human Hepatitis B } \\
\text { Virus } \\
(\mathrm{HBV})\end{array}$ & $\begin{array}{l}\text { Envelope small }(\mathrm{S}) \text { protein, } \\
\text { middle }(\mathrm{M}) \text { protein, and large } \\
(\mathrm{L}) \text { protein }\end{array}$ & $\begin{array}{l}\text { Glypican-5, sodium-taurocholate co-transporting } \\
\text { polypeptide (NTCP), epidermal growth factor } \\
\text { receptor (EGFR), E-cadherin, asiaglycoprotein } \\
\text { receptor, transferrin receptor, IL-6 receptor, } \\
\text { polymerized human albumin receptor }\end{array}$ & [40-43] \\
\hline $\begin{array}{l}\text { Human Hepatitis C } \\
\text { Virus } \\
\text { (HCV) }\end{array}$ & Glycoproteins E1 and E2 & $\begin{array}{l}\text { Apolipoprotein E, syndecan-1 and -4, scavenger } \\
\text { receptor class B1 (SR-BI), claudin-1, occludin, T cell } \\
\text { immunoglobulin and mucin domain } \\
\text { 1(TIM-1)—containing proteins }\end{array}$ & [44-48] \\
\hline $\begin{array}{l}\text { Human Hepatitis E } \\
\text { Virus } \\
\text { (HEV) }\end{array}$ & $\begin{array}{l}\text { Open reading frame } 2 \text { protein } \\
\qquad(\mathrm{pORF} 2)\end{array}$ & $\begin{array}{c}\text { Asialoglycoprotein receptor } \frac{1}{2} \text { (ASGPR1/2), integrin } \\
\alpha 3 \text {, syndecan- } 1 \text {, ATP synthase subunit } 5 \beta \\
\text { glucose-regulated protein } 78 \text { (GRP78) }\end{array}$ & {$[49,50]$} \\
\hline $\begin{array}{l}\text { Human Papilloma } \\
\text { Virus } \\
(\mathrm{HPV})\end{array}$ & L1 and L2 proteins & Syndecans, $\alpha 6$ integrin, EGFR, tetraspanins & [51-54] \\
\hline $\begin{array}{l}\text { Merkel Cell } \\
\text { Polyomavirus } \\
\text { (MCPyV) }\end{array}$ & Capsid proteins VP1 and VP2 & Sialylated glycans, sulfated HS & {$[55,56]$} \\
\hline $\begin{array}{l}\text { Metapneumovirus } \\
\quad(\mathrm{HMPV})\end{array}$ & $\begin{array}{l}\text { Glycoprotein } \mathrm{G} \text {, small } \\
\text { hydrophobic }(\mathrm{SH}) \text { protein, } \\
\text { and fusion }(\mathrm{F}) \text { protein }\end{array}$ & Ephrin B2, $\beta 1$ integrin, HSPGs & {$[57,58]$} \\
\hline $\begin{array}{l}\text { Rabies Virus } \\
\quad(\text { RABV) }\end{array}$ & $\begin{array}{l}\text { M (matrix) and } G \\
\text { (glycoprotein) proteins }\end{array}$ & $\begin{array}{c}\text { Nicotinic acetylcholine receptor (nAChR), neuronal } \\
\text { cell adhesion molecule (NCAM), p75 neurotrophin } \\
\text { receptor (p75NTR), metabotropic glutamate receptor } \\
\text { subtype } 2 \text { (mGluR2), HSPGs, phospholipids, } \\
\text { gangliosides }\end{array}$ & [59-61] \\
\hline $\begin{array}{l}\text { Respiratory Syncytial } \\
\text { Virus } \\
\text { (RSV) }\end{array}$ & $\begin{array}{l}\text { Attachment glycoprotein }(\mathrm{G}) \text {, } \\
\text { and fusion glycoprotein }(\mathrm{F})\end{array}$ & $\begin{array}{c}\text { Intercellular adhesion molecule-1 (ICAM-1), Toll-like } \\
\text { receptor } 4 \text { (TLR4), nucleolin, surfactant protein A } \\
\text { (SP-A), HSPGs, annexin II }\end{array}$ & [62-65] \\
\hline $\begin{array}{l}\text { Severe Acute } \\
\text { Respiratory Syndrome } \\
\text { Coronavirus-2 } \\
\text { (SARS-CoV-2) }\end{array}$ & Spike $(S)$ protein & $\begin{array}{l}\text { ACE2 receptor, neuropilin-1 (NRP1), } \\
\text { tyrosine-protein kinase receptor UFO (AXL), HSPGs }\end{array}$ & [66-69] \\
\hline
\end{tabular}

In some cases, virus attachment to HSPGs allows conformational changes of the viral proteins involved in the entry, facilitating their interaction with uptake receptors and 
subsequent infectious internalization. Several human papilloma virus (HPV) serotypes depend on HSPGs for their initial attachment to the host cells [51-53], and it has been shown that, following the interaction with HSPGs, the HPV capsid proteins L1 and L2 undergo conformational changes mediated by cyclophilin B, kallikrein-8, and furin, resulting in reduced affinity for HSPG binding, and transfer to entry receptors such as $\alpha 6$ integrins, epidermal growth factor receptor (EGFR), and tetraspanins [54]. Among the viruses whose interaction with HSPGs on the host cell surface is a prerequisite for entering and infecting target cells, there are many types of coronaviruses, including human coronavirus NL63 (HCoV-NL63) and severe acute respiratory syndrome coronavirus-2 (SARS-CoV2) $[27,28,66]$. Both these viruses employ the functional angiotensin-converting enzyme 2 (ACE2) receptor to enter and infect the host cells; however, the first attachment of HCoV-NL63 involves the viral membrane (M) protein binding to HSPGs [28], whereas SARS-CoV-2 uses the spike (S) protein to interact with HSPGs [66]. The interaction of the $S$ protein of SARS-CoV-2 with the cell surface HSPGs triggers a conformational change of the receptor-binding domain $(\mathrm{RBD})$ of the $S$ protein that favors the binding of the virus to its specific receptor (ACE) [66].

At times, HSPGs may serve as viral receptors themselves [24,36,55,62,70-73]. This is the case for herpes simplex virus serotypes 1 and 2 (HSV-1 and HSV-2), whose viral envelope glycoproteins $\mathrm{gB}$ and $\mathrm{gC}$ bind HSPGs to promote attachment, to slide down membrane projections such as filopodia, and to reach the cell body for membrane penetration [73]. Then the binding of $\mathrm{gD}$ to nectin-1 or 3-O-sulfated HS triggers conformational changes recruiting $\mathrm{gB}, \mathrm{gH}$, and $\mathrm{gL}$ for membrane fusion leading to capsid release in the cytoplasm [36]. Similarly, the human respiratory syncytial virus (RSV), which is characterized by three envelope proteins - the attachment glycoprotein $(\mathrm{G})$, the fusion protein $(\mathrm{F})$, and the small hydrophobic protein $(\mathrm{SH})$ - uses its $\mathrm{G}$ and $\mathrm{F}$ proteins to interact directly with HSPGs and to infect host cells [62]. The subsequent fusion process mediated by the F protein allows entry of the viral genome into host cells. The host cell HSPGs also serve as initial attachment receptors for the Merkel cell polyomavirus (MCV) prior to secondary interactions with a sialylated co-factor during the infectious entry process [55].

Many viruses exploit HSPG-mediated endocytosis to enter host cells [74]. The HSPGregulated endocytic pathways utilized by the virus to enter host cells include clathrinmediated uptake, or caveolae/cholesterol-dependent endocytosis, and macropinocytosis. Investigations on the human hepatitis B (HBV) entry pathway have demonstrated that the cellular uptake of the virus is driven by HSPG-mediated endocytosis rather than by the cell-surface sodium taurocholate cotransporting polypeptide (NTCP) receptor [75]. The proposed model implies that the L protein domains of HBV are involved in the attachment to HSPGs on human hepatic cells, the initiation of endocytosis, the interaction with NTCP in endosomes triggering membrane fusion, and the subsequent endosomal escape. Interestingly, a targeted RNA interference entry screen allowed researchers to identify glypican-5 as a preferential HBV entry factor; because this HSPG is highly expressed on the liver, the HBV-glypican-5 interaction may partly account for the strong hepatotropism of HBV [42]. Furthermore, a model for HPV entry into host cells suggests that the HPV endocytosis occurs after the binding of capsid proteins to HSPGs on either the epithelial cell surface or the basement membrane, and other signaling molecules such as growth factors and $\alpha 6$-integrins [51]. On the other hand, in HIV infection, HSPGs interact with both gp120 glycoprotein and the trans-activator of transcription (Tat) protein, which enhances transcription and viral virulence during infectivity and promotes virus internalization into a variety of different cell types through caveolar endocytosis [76,77]. Finally, HSPGs have been suggested to serve as assisting cofactors for ACE2-mediated endocytosis of HCoV-NL63 [27] and SARS-CoV-2 [78].

Some viruses that do not require binding to HSPGs to attach and to infect host cells may acquire HSPG dependence following intra-host or cell culture adaptation. There is abundant evidence that several viruses-including rhinoviruses [79,80], Coxsackie virus B3 [81], Sindbis virus [82,83], Ross River alphavirus [84], flavivirus tick-borne encephalitis 
virus $[85,86]$, and others-during repeated passage in cell culture undergo adaptation changes leading to an augmented ability to binding HS, a phenomenon that may provide a selective advantage to the viruses [25]. Similar viral adaptations occurring in cell cultures may also take place during human infections, generating viral variants that can show different tropism, virulence, and pathogenicity than parental viruses [25,87-91]. One example is provided by enterovirus 71 (EV71), whose mutation acquired during the infection of an immunocompromised host enabled the virus to bind HS, thus modifying viral tropism in neural, intestinal, and respiratory tissues [87]. On the other hand, mutants of JC polyomavirus, the causative agent of progressive multifocal leukoencephalopathy, show an increased ability to bind HSPGs and infect neural cells, which express high levels of syndecans and glypicans $[25,88]$. Several SARS-CoV-2 mutations affecting the S protein sequence have emerged [89-91], but additional studies are needed to establish whether and how such mutations impact the ability of the S protein to bind HSPGs and, in turn, on infection, tropism, immunity, and pathogenesis of SARS-CoV-2.

Of note, cell culture adaption mediated by HS may promote attenuation of viral virulence. Indeed, in some cases, HS attachment may inhibit rather than enhance the dissemination of HS-binding viruses [32,92-98]. A trapping effect of cell surface HSPGs has been demonstrated in vivo through the injection into mice of two enterovirus A71 mutants that resulted in a higher virulence of the HS-non-binding mutant with respect to that of the HS-binding one. Indeed, although HSPGs are expressed by many cultured cell lines and increase the infection by a subset of EV-A71 strains, they are not expressed by cells that express the SCARB2 viral receptor at high levels in vivo. Thus, HS-positive cells merely adsorb the virus and do not contribute to replication or dissemination of the virus in vivo [92]. Attenuation of viral pathogenicity through the acquisition of HS-binding ability in cell cultures has also been reported for DENV [93], Sindbis virus [83], encephalitis viruses [94], foot and mouth disease virus [95], and others. On the other hand, in vivo HSPGs may not only facilitate the concentration of the virus at the cell surface, enhancing the probability of access to the related entry receptors, but they may also trap the viral particles at the surface of non-permissive cells and mediate in trans infection by allowing the virus to interact with entry receptors on permissive cells $[96,97]$. For example, the high levels of syndecan-3 expressed by the endothelial cells of lymphoid tissues capture HIV particles and present them to permissive T cells [98].

\section{Role of Heparan Sulfate Proteoglycan Biosynthetic and/or Modifying Enzymes in Viral Infections}

Beyond the evidence that viruses use HSPGs for attachment and entry into host cells, either HSPG biosynthetic or post-synthetic modifying enzymes have emerged as critical players in the viral invasion of target cells at various steps of their life cycles $[4,7,99]$. Table 2 reports a list of the viruses whose ability to enter and to infect host organisms is regulated by the differential activity of HSPG biosynthetic and/or modifying enzymes [100-109]. The 3-O-sulfation of HS chains catalyzed by 3-O-sulfotransferases (3-OSTs) is required for the internalization and spread of human cytomegalovirus (CMV) [100] and HSV-1 [33,70,72], whereas 3-OST isoform B is downregulated in the hepatocytes of chronic HBV infection [106]. Furthermore, while HS modified by the 3-OST isoform 3 has been suggested to increase SARS-CoV-2 cell-to-cell fusion [109], a preferential recognition of the $S$ protein receptor binding domain (RBD) by $\mathrm{N}$ - and 6-O-sulfated HS sequences has been identified [66]. In addition, 6-O- and $\mathrm{N}$-sulfation of GlcNAc of HS is a critical determinant for coxsackievirus B3 variant PD interaction with the host cell [101] as well as for HCV infection [44,47], and efficient rabies virus infection of target cells [59], whereas $\mathrm{N}$-sulfation, but not C6-Oor C2-O-sulfation, is important for RSV infection [63,108]. Furthermore, 6-O-sulfated groups of HS are essential to promote the interaction of HIV glycoprotein gp120 with HSPGs on the surface of host cells, enabling virus attachment, fusion, and entry into the cells $[37,38]$. A similar requirement for 6-O-sulfation has also been shown for the interaction of HEV pORF2 capsid protein with the syndecans on the cell surface [49]. 
Table 2. HS synthetizing and/or modifying enzyme(s) involved in the pathogenesis of human viral infections.

\begin{tabular}{|c|c|c|c|}
\hline Virus & $\begin{array}{l}\text { HS Synthetizing } \\
\text { and/or Modifying } \\
\text { Enzyme(s) }\end{array}$ & Role of Enzyme(s) in Viral Pathogenesis & Reference(s) \\
\hline $\begin{array}{l}\text { Cytomegalovirus } \\
\text { (CMV) }\end{array}$ & 3-OST & 3-O-sulfation in HS chains supports viral entry, and cell-to-cell fusion & [100] \\
\hline $\begin{array}{l}\text { Coxsackieviruses } \\
\text { B3 variant PD } \\
\text { (CVB3 PD) }\end{array}$ & NDST1 and 6-OST & $\begin{array}{l}\mathrm{N} \text { - and 6-O-sulfated HS chains mediate viral attachment and } \\
\text { internalization }\end{array}$ & [101] \\
\hline $\begin{array}{l}\text { Dengue Virus } \\
\quad(\mathrm{DENV})\end{array}$ & $\begin{array}{l}\text { Heparanase and } \\
\text { cathepsin L }\end{array}$ & $\begin{array}{l}\text { Upregulation of cathepsin L and heparanase by the viral } \\
\text { non-structural protein } 1 \text { (NS1) binding to HS on endothelial cells } \\
\text { triggers syndecan-1 shedding leading to hyperpermeability of } \\
\text { endothelial cells in vitro and systemic vascular leakage in vivo }\end{array}$ & {$[102,103]$} \\
\hline $\begin{array}{l}\text { Herpes Simplex } \\
\text { Virus type } 1 \\
\text { (HSV-1) }\end{array}$ & Heparanase & $\begin{array}{l}\text { O-sulfation at C3 position of GlcN residues promotes viral } \\
\text { attachment and entry } \\
\text { Upregulation of heparanase in response to viral infection results in } \\
\text { the facilitation of the virus spread to uninfected cells and tissues }\end{array}$ & {$[104,105]$} \\
\hline $\begin{array}{l}\text { Human Hepatitis B } \\
\text { Virus } \\
\text { (HBV) }\end{array}$ & 3-OST & $\begin{array}{l}\text { High levels of 3-O-sulfated HS chain suppress viral replication in } \\
\text { hepatocytes }\end{array}$ & [106] \\
\hline $\begin{array}{l}\text { Human Hepatitis } \\
\text { C Virus } \\
(\mathrm{HCV})\end{array}$ & NDST1 and 6-OST & $\begin{array}{l}\mathrm{N} \text { - and 6-O-sulfation of HS chains are required for viral attachment } \\
\text { and infection }\end{array}$ & {$[44,47]$} \\
\hline $\begin{array}{l}\text { Human Hepatitis E } \\
\text { Virus } \\
\text { (HEV) }\end{array}$ & $6-\mathrm{OST}$ & $\begin{array}{l}\text { 6-O-sulfation of syndecans is required for viral attachment and } \\
\text { infection }\end{array}$ & [49] \\
\hline $\begin{array}{l}\text { Human } \\
\text { Immunodeficiency } \\
\text { Virus } \\
\text { (HIV) }\end{array}$ & 6-OST & $\begin{array}{l}\text { 6-O-sulfation of syndecan HS chains is required for gp120 viral } \\
\text { protein binding to host cell surface }\end{array}$ & {$[37,38]$} \\
\hline $\begin{array}{l}\text { Human Papilloma } \\
\text { Virus serotype } 16 \\
\text { (HPV-16) }\end{array}$ & $\begin{array}{l}\text { Sheddases (MMPs } \\
\text { and ADAMs) and } \\
\text { heparanase }\end{array}$ & $\begin{array}{l}\text { Shedding of syndecan- } 1 \text { and heparanase processing are essential } \\
\text { steps in the viral release from ECM, cellular uptake, and infection }\end{array}$ & {$[7,53,107]$} \\
\hline $\begin{array}{l}\text { Rabies Virus } \\
\quad(\text { RABV) }\end{array}$ & NDST and 6-OST & $\begin{array}{l}\mathrm{N} \text { - and 6-O-sulfation of HS chains are required for viral attachment } \\
\text { and infection }\end{array}$ & [59] \\
\hline $\begin{array}{l}\text { Respiratory } \\
\text { Syncytial Virus } \\
\quad(\text { RSV) }\end{array}$ & NDST & $\begin{array}{l}\text { N-sulfation at C-6 position of GlcN triggers viral attachment and } \\
\text { cell-membrane fusion }\end{array}$ & {$[63,108]$} \\
\hline Severe Acute & NDST1 and 6-OST & $\begin{array}{l}\text { N- and 6-O-sulfation of HS chains are required for the viral } \\
\text { attachment and infection }\end{array}$ & {$[66]$} \\
\hline $\begin{array}{l}\text { Respiratory } \\
\text { Syndrome }\end{array}$ & 3-OST & $\begin{array}{l}\text { 3-O-sulfated HSPGs contribute to the viral cell-to-cell fusion } \\
\text { Heparanase activity on HSPGs present on the surface of endothelial }\end{array}$ & [109] \\
\hline $\begin{array}{l}\text { Coronavirus-2 } \\
\text { (SARS-CoV-2) }\end{array}$ & Heparanase & $\begin{array}{c}\text { cells disrupts the endothelial glycocalyx with subsequent loss of } \\
\text { endothelial barrier function. Upregulation of heparanase is } \\
\text { associated with severe forms of infection }\end{array}$ & [110] \\
\hline
\end{tabular}

A key role of HSPG-modifying enzymes such as sheddases, heparanases, and endosulfatases (SULFs) in the pathogenesis of viral infections has been demonstrated [7,99]. During the infection process, HSPGs can trap the viral progenies, inhibiting their release and spread; hence, HS-binding viruses have developed mechanisms to circumvent such a problem. These mechanisms may involve either the upregulation of heparanase that degrades the HS polysaccharide backbone or the activation of proteases that shed the protein core of HSPGs [99]. Upregulation of heparanase in response to HSV-1 infection results in the shedding of HS chains from the plasma membrane of infected cells that lose the 
capability to trap the newly synthesized virions, thus allowing their spread to other cells and tissues [104,105]. Syndecan-1 shedding by heparanase is an essential step in the dengue virus (DENV) infection; this action leads to hyperpermeability of human endothelial cells in vitro and systemic vascular leakage in vivo $[102,103]$. These effects are mediated by the secreted DENV non-structural protein 1 (NS1), which disrupts the endothelial glycocalyx layer through the activation of sialic acid degradation and HSPG shedding. In particular, NS1 upregulates sialidases and heparanase and activates cathepsin L, which in turn activates heparanase by enzymatic cleavage [102]. Inhibition of syndecan-1 shedding by MMPs, ADAMs, and/or heparanase greatly reduces cellular uptake of HPV serotype 16 and subsequent infection $[7,53,107]$. During infection, HPV-16 mainly attaches to ECM components of keratinocytes through HS chains of syndecan-1, and the action of HSPG processing enzymes is relevant to the release of infectious viral particles from the ECM and to an efficient infection of keratinocytes [53]. The involvement of heparanase, acting by lowering $\mathrm{N}$-sulfation and iduronic acids units of HS chains, thus reducing infection, has been shown in different cell lines infected by RSV [63,108]. A contribution of heparanase to the pathogenesis of SARS-CoV-2 infections has been also suggested because elevated activity of the enzyme together with high levels of HS were found in the plasma of patients affected by SARS-CoV-2 infectious disease (COVID-19); these factors are associated with the severity of the disease. The proposed mechanisms to explain heparanase involvement in the severe forms and worsened outcomes of COVID-19 include its well-established roles in the degradation of the endothelial glycocalyx and the activation of inflammatory responses [110]. These findings and other evidence suggest that biosynthetic and/or posttranslational modifying enzymes are important for the interaction of viruses with host cells and the infection process. However, further structure-function analyses of modified-HS chains in different tissues and organs might provide more insights into the pathogenesis of viral diseases and could be useful for developing novel potential diagnostic tools and therapeutic interventions.

\section{Heparan Sulfate Proteoglycan Involvement in the Pathogenicity of SARS-CoV-2}

SARS-CoV-2 is a member of the Coronaviridae family, the order Nidovirales, and the former genus Coronavirus, which has been split into four genera (see below). Coronaviruses (CoVs) are enveloped positive single-stranded RNA viruses with a large genome of 28-32 kb that infect a wide spectrum of animal species including humans [111]. They are classified into four genera: Alphacoronavirus, Betacoronavirus, Gammacoronavirus, and Deltacoronavirus. However, only seven types of CoVs belonging to the Alphacoronavirus and Betacoronavirus genera cause infections in humans, with variable outcomes. Four of them, namely HCoV-229E, HCoV-OC43, HCoV-NL63, and HCoV-HKU1, cause mild and self-limiting infections of the upper respiratory tract, whereas the SARS-CoV, the recent SARS-CoV-2, and the Middle East respiratory syndrome coronavirus (MERS-CoV) result in serious respiratory tract infections leading to pneumonia and renal failure, with an elevated mortality rate [112].

The coronavirus particles are composed of a nucleocapsid protein $(\mathrm{N})$ surrounding the viral genomic RNA, and an envelope bearing a membrane protein (M), an envelope protein (E), and a spike protein (S) [112,113]. However, additional structural proteins have been identified for some $\mathrm{CoVs}$, such as hemagglutinin esterase and accessory open reading frame (ORF) proteins that are not essential for viral replication but seem to have a role in viral pathogenesis [114]. Although viral entry into host cells may involve different structural proteins, the major envelope $S$ protein mediates the attachment of $\mathrm{CoV}$ particles to cell surface molecules and receptors as well as the fusion between the virus and the cell membrane. The $\mathrm{S}$ protein contains three segments: a large ectodomain, a transmembrane anchor, and a short tail. The ectodomain is composed of two subunits: the S1 subunit is involved in the binding of receptors on the host cell surface, and the S2 subunit is required for fusing host and viral membranes. In most CoVs, the C-terminus of the S1 (S1-CTD) domain contains one or more receptor binding sites (RBSs), which may be highly 
divergent among different $\mathrm{CoV}$ types, whereas the N-terminus of the S1 region (S1-NTD) is more conserved and mainly contributes to the initial binding to the attachment factors on the host cell surface [113]. Among the receptors recognized by the S1-CTD are the zinc aminopeptidase N (APN) for HCoV-229E [115]; the serine dipeptidyl peptidase 4 (DPP4) for MERS-CoV [116]; and the zinc peptidase ACE2 for HCoV-NL63, SARS-CoV, and SARS-CoV-2 $[26,66,117]$. However, in SARS-CoV-2, the cleavage of $S$ protein by host furin into the $\mathrm{S} 1$ and $\mathrm{S} 2$ subunits generates a polybasic sequence in $\mathrm{S} 1$ that binds the cell surface neuropilin-1 (NRP1) receptor, potentiating virus infectivity $[67,68]$. Although both SARS$\mathrm{CoV}$ and SARS-CoV-2 use the ACE2 receptor to infect host cells, the SARS-CoV-2 S1 protein binding to NRP1 could explain the different tropism of the two related viruses, with SARS$\mathrm{CoV}$ infection occurring predominantly in the lower respiratory system [118] whereas SARS-CoV-2 rapidly spreads through active pharyngeal viral shedding [119]. Indeed, while ACE2 is expressed at low levels in respiratory and olfactory epithelial cells [120], NRP1 is highly expressed in the respiratory and olfactory epithelium. Recently, a novel receptor, the tyrosine-protein kinase receptor UFO (AXL) that specifically interacts with the N-terminal domain of SARS-CoV-2 S protein, has been shown to promote the entry of SARS-CoV-2 into the cells of the respiratory system, such as pulmonary and bronchial epithelial cells [69].

Prior to the specific interaction with the entry receptors, $\mathrm{CoV}$ infection requires the initial binding of the viral envelope proteins with host cell surface molecules such as carbohydrates and glycoproteins that leads to the local viral enrichment prior to internalization. For example, HCoV-HKU1 and HCoV-OC43 bind O-acetylated sialic acid [121], although HCoV-HKU1 also recognizes the major histocompatibility complex class I C (HLA-C) as attachment molecule [122], and HCoV-OC43 has also been shown to attach to HS during adaption in cell culture [123]. Similarly, binding of SARS-CoV proteins to dendritic cell-specific intercellular adhesion molecule-3-grabbing nonintegrin (DC-SIGN) and DC-SIGN-related protein (also termed L-SIGN) enhances infection [124]. MERS-CoV exploits carcinoembryonic antigen-related cell adhesion molecule 5 (CEACAM5) [125], tetraspanin CD9 [126], and the 78-kDa glucose-regulated protein (GRP78) [127] as attachment factors that facilitate viral entry. On the other hand, effective adhesion to cell surface HSPGs enhancing the infection process has been reported for different types of animal and human CoVs, including CoV-NL63, SARS-CoV, and SARS-CoV-2 [27,66,81]. In particular, HS has been definitively identified as an attachment receptor for SARS-CoV-2 infection in in vitro human lung epithelial cells and ex vivo human lung tissue explants [128].

Since 2020, a substantial number of studies have addressed the role and the mechanisms underlying the interaction between the viral envelope $S$ protein of SARS-CoV-2 and the HSPGs that provide the first anchoring sites for the virus on the host cell surface $[66,81,129-132]$. It has been established that the binding of the $S$ protein of SARS-CoV-2 to the host cells requires the engagement of both HS and ACE2 [131], thus suggesting that HSPGs act as a co-receptor for the S protein interaction with the ACE2 entry receptor [66]. The binding of S1-NTD to HSPGs allows the initial contact between SARS-CoV-2 and the host cell, facilitating the concentration of the virus at the cell surface and its access to ACE2. In particular, the ectodomain of the $S$ protein interacts with cell surface HS chains through the S1 receptor-binding domain (RBD) that binds the peptidase domain of ACE2 [133]. Indeed, the trimeric $S$ protein of SARS-CoV-2 contains a group of positively charged amino acid residues such as R346, R355, K444, R466, and R509 that are localized in a position adjacent to the ACE-binding site and exposed in the RBD, thus representing the potential sites of interaction with HS chains [66]. Interestingly, a single RBD may simultaneously bind both cell surface HS chains and the ACE receptor [66]. Surface plasmon resonance (SPR) and circular dichroism spectroscopy have demonstrated that heparin, which is structurally similar to HS, binds and induces a conformational change in the RBD domain of the SARS-CoV-2 S1 protein [134]. This binding is more dependent on the presence of 2-O- or 6-O-sulfated groups than $\mathrm{N}$-sulfated HS domains. Furthermore, studies support a model in which the RBD of SARS-CoV-2 S protein lends sequence specificity for $\mathrm{HS}$ on target cells, 
while an additional binding site at the S1/S2 proteolytic cleavage site enhances the affinity of the binding to HS $[135,136]$.

The elegant work by Clausen and co-workers provides strong data supporting a model in which HSPGs serve as "collectors" of viral particles and "mediators" of the RBD-ACE2 interaction, thus triggering more efficient infection [66]. After the contact of the SARS-CoV-2 $S$ protein with HSPGs and ACE2 receptor, host cell membrane proteases prime the $S$ protein to carry out efficient internalization through the process of membrane enfolding [137]. In particular, the S2 subunit of the S protein ectodomain drives the fusion of the viral envelope with the membrane of host cells. However, virus-cell membrane fusion requires $\mathrm{S}$ protein cleavage at the S1/S2 boundary site by furin. The furin cleavage of the $S$ protein is essential for efficient replication of SARS-CoV-2 in human lung epithelial cells [135]. Furthermore, the $\mathrm{S} 2$ subunit undergoes an additional cleavage into fusion peptide (FP) and S2' domains through the action of the cellular serine protease TMPRSS2 (transmembrane protease serine-2) that cleaves the $\mathrm{S} 2$ ' site, or the endosomal cysteine proteases cathepsin B and L (CatB/L) [136,137]. The activity of cysteine cathepsins is strictly regulated by HSPGs that promote their autocatalytic activation as well as conformational changes that increase their affinity for the substrate and enhance their activity $[5,138]$.

Some reports suggest that the HSPGs also act as assisting cofactors in SARS-CoV-2 endocytosis. Through this route, the ACE2-bound virus may use the endosomal pathway to move through the cytoplasm, where it starts replication and exits from the cells to transfect the neighboring cells [81]. The contribution of HSPGs to this process has been suggested based on evidence showing that SARS-CoV-2 entry into the cells is prevented by ablating genes involved in HSPG biosynthetic machinery or employing HS mimetics targeting endocytic pathways $[81,139]$. Furthermore, a Food and Drug Administration (FDA)-approved drug that blocks HS-dependent endocytosis of $\alpha$-synuclein ( $\alpha$-Syn) fibrils is able to inhibit SARS-CoV-2 infection [22,140]. Finally, in vitro cellular assays supported by computational studies showed that HSPGs modified by the 3-OST isoform 3, but not the 3-OST isoform 5, increase the S-protein-mediated cell-to-cell fusion of SARS-CoV-2, thus suggesting a role for HSPGs in viral spread [109].

The primary site of SARS-CoV-2 infection is the human upper and lower respiratory tract [141,142], although the virus can infect other organs [143-145]. Once SARS-CoV-2 enters the host through the respiratory tract, its first targets are the airway and alveolar epithelial cells, the vascular endothelial cells, and the alveolar macrophages [119]. HSPGs play important roles in maintaining parenchymal architecture and pulmonary homeostasis and facilitating cell signaling required for lung development and functions [146]. While it is unclear whether alveolar epithelial cell surface HS contributes to the epithelial surface layer, the sulfation pattern of epithelial HSPGs significantly impacts the alveolar intercellular signaling and the epithelial cell phenotype $[147,148]$. The HSPGs abundantly expressed on the alveolar basement membrane serve to connect the alveolar endothelium and epithelium, whereas in the pulmonary endothelial glycocalyx they contribute to the endothelial barrier function [149]. In pulmonary vasculature, HSPGs play an important role in angiogenesis and smooth muscle cell activation [146].

Abundant evidence has shown that SARS-CoV-2 infection promotes endothelial dysfunction and vascular leakage [150-153]. Autopsies on patients who died of COVID19 have revealed in the lungs severe endothelial injury associated with the presence of intracellular virus and disrupted cell membranes, and widespread vascular thrombosis with microangiopathy [154,155]. Viral inclusions into endothelial cells of glomerular capillary loops and widespread endotheliitis in the lung, heart, liver, kidney, and gut were detected in the autoptic specimens of patients affected by severe forms of COVID19 [152]. The multi-organ endothelial dysfunctions observed in COVID-19 patients are likely due to the ubiquitous expression of SARS-CoV-2 receptor ACE2 in organs such as the lung, gut, kidney, brain, testis, heart, and mainly in the vascular system, where high levels of the receptor are present in the endothelial cells of either small or large arteries and veins $[156,157]$. However, the expression levels of ACE2 in the tissues (including 
the vascular system) of males and females as well as of younger and older people do not fully explain the different severity of COVID-19 observed in such distinct populations. Hence, other host cell factors likely play a determinant role in the development of lethal complications in COVID-19 patients.

Under the condition of old age and/or comorbidities, including chronic obstructive pulmonary disease, hypertension, cardiovascular disease, diabetes, and obesity, damage of the vascular endothelial glycocalyx has been associated with poor prognosis in severe COVID-19 patients [158]. The glycocalyx is a gel-like layer covering the surface of all living cells; it is composed of a membrane-binding domain consisting of sialic acidcontaining glycoproteins, syndecans, HS, and hyaluronic acid (HA). The endothelial glycocalyx plays a critical role in maintaining vascular homeostasis and regulating the interaction between vascular endothelial cells and blood components $[159,160]$. A variety of cellular stresses may damage the vascular endothelial glycocalyx, and the damage is known to be sex specific, mostly observed in men [161]. Systemic degradation of the vascular endothelial glycocalyx occurring in serious infections and other severe pathologies such as sepsis and inflammation, atherosclerosis, ischemia and hypoxia, diabetes, and renal diseases leads to thinning of the glycocalyx layer and increased vascular permeability [158-163]. Elevated concentrations of fragmented vascular endothelial glycocalyx, such as syndecan-1, syndecan-4, HA, and HS, have been observed in the blood of patients affected by chronic kidney disease [164], acute decompensated heart failure [165], diabetes [166], cardiac surgery [167], Crohn's disease [168], and others. Elevated levels of HS were found in the plasma from subjects with respiratory failure due to lung injury, and HS concentrations correlated with intensive care unit length of stay [169]. Recently, circulating levels of fragmented vascular endothelial glycocalyx have been detected in sublingual capillaries of patients with COVID-19 [158]. Damage of the vascular endothelial glycocalyx occurs more easily in elderly people than in young people, and in people with common comorbidities [158]; researchers suggest that this difference represents a mechanism for the development of fatal complications in COVID-19 patients. Furthermore, sex differences in COVID-19 severity and mortality could derive from sex differences in the vascular endothelial glycocalyx constituents, including HSPGs $[158,161]$. Thus, as a consequence of the strict requirement of the $S$ protein binding to HS for ACE interaction, and the prominent role of HSPGs in the structure and function of the vascular endothelial glycocalyx, it follows that the extraordinary structural variety of HSPGs generated by synthetic and post-synthetic modifying enzymes as well as the key regulatory functions exerted by HSPGs in different cell types and tissues — which depend on the sex and age of individuals [170,171] — might strongly contribute to the tissue tropism [141-146], as well as the different susceptibility of distinct patient populations to SARS-CoV-2 infection [158,161,172,173].

\section{Perspective for Therapeutic Intervention against SARS-CoV-2 by Targeting HSPGs}

The growing evidence on the involvement of HSPGs in the SARS-CoV-2 pathogenicity has prompted many researchers to suggest the development of therapeutic strategies targeting HSPGs to combat the infection and transmission of the virus in the human population. Drugs targeting HSPGs represent valuable candidates to interfere with the viral attachment to target cells, the early stages of virus-receptor interaction, the virus-cell membrane fusion, the viral endocytosis, and the viral spread (Figure 2).

For this purpose, the development of antibodies directed against HS, heparin/HSbased oligosaccharides, small HS mimetics, HS-degrading lyases, inhibitors of the HS biosynthetic machinery, and inhibitors of serine or cysteine proteases (i.e., cathepsins) involved in the viral endocytosis might prove useful therapeutic strategies to fight SARSCoV-2 infection $[9,20,38,66,75,81,132,139,174-178]$. Table 3 reports some examples of HSPGtargeting therapeutics that have been proposed to be used alone or in combination with other drugs to block the infectious cycle of SARS-CoV-2. 


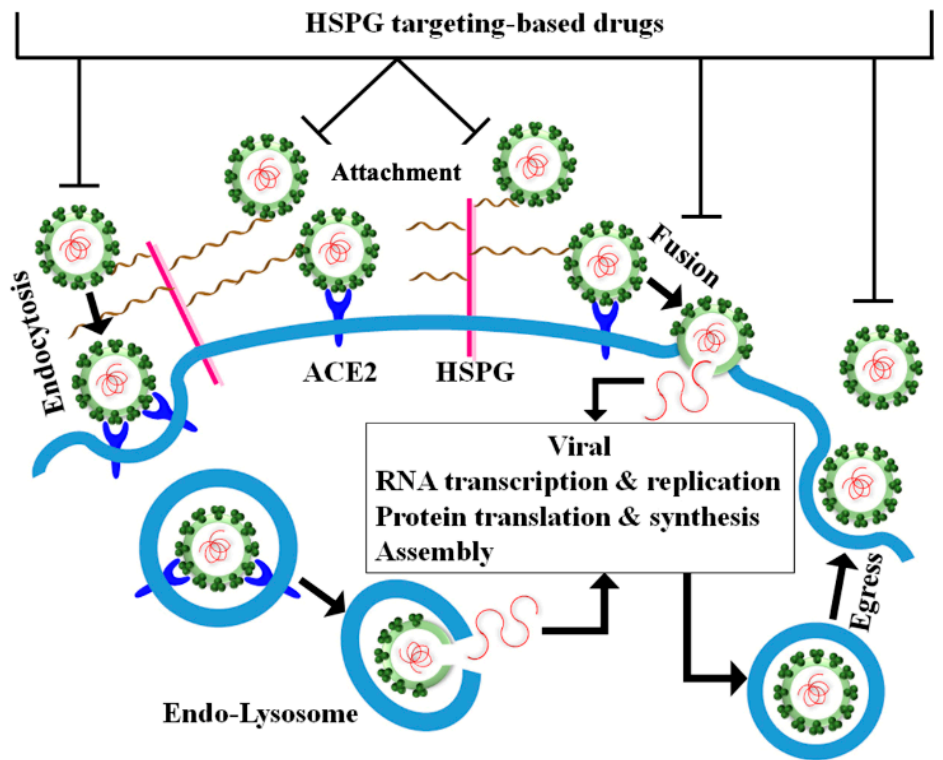

Figure 2. Schematics of the potential action of HSPG-targeting drugs in SARS-CoV-2 infection. HS binding compounds may compete with the viral particles for attachment to the HSPGs, thus inhibiting the viral engagement of HS chains and the subsequent access to the ACE2 receptor. Consequently, the viral entry by either fusion or endocytosis may be impaired.

Table 3. HSPG-targeting therapeutics that might be useful against SARS-CoV-2 infection.

\begin{tabular}{|c|c|c|c|}
\hline Drug & Chemical Type & Mechanism of Action & Reference(s) \\
\hline Heparin & Glycosaminoglycan & $\begin{array}{l}\text { Competes with the binding of the viral S protein to the } \\
\text { HS chains of cell surface HSPGs, thus inhibiting entry }\end{array}$ & $\begin{array}{c}{[66,81,130,132,134,} \\
179-183]\end{array}$ \\
\hline HBPs & $\begin{array}{l}\text { Heparin binding peptides } \\
\text { conjugated with CMR-197 } \\
\text { protein carrier }\end{array}$ & $\begin{array}{l}\text { Inhibit HSPG-dependent viral internalization; escape } \\
\text { the endosomal pathway and enter cytoplasm to target } \\
\text { cytoplasmic virus; antagonize viral replication and } \\
\text { cell-to-cell transmission }\end{array}$ & {$[175,184-189]$} \\
\hline BNTX & $\begin{array}{l}\text { 7(E)-Benzylidenenaltrexone; } \\
\text { opioid receptor antagonist }\end{array}$ & Disrupts the actin network impairing viral endocytosis & [81] \\
\hline Lactoferrin & Iron-binding glycoprotein & Prevents the virus internalization by binding HSPGs & [190-196] \\
\hline Mitoxantrone & $\begin{array}{l}\text { Synthetic anthraquinone } \\
\text { derivative }\end{array}$ & Prevents the viral entry by binding HSPGs & {$[81,197]$} \\
\hline $\begin{array}{l}\text { Mupafostat } \\
\text { (PI-88) }\end{array}$ & $\begin{array}{c}\text { Highly sulfated, } \\
\text { monophosphorylated } \\
\text { mannose oligosaccharide }\end{array}$ & $\begin{array}{l}\text { Inhibits heparanase activity, preventing viral release and } \\
\text { cell-to-cell spread }\end{array}$ & [198-202] \\
\hline PDSTPs & $\begin{array}{l}\text { Dispirotripiperazinium } \\
\text { derivatives }\end{array}$ & Bind cell surface HSPGs, inhibiting viral attachment & [203] \\
\hline $\begin{array}{l}\text { Roneparstat } \\
\text { (SST0001) }\end{array}$ & HS mimetics & $\begin{array}{l}\text { Prevents the heparanase activity of HS removal from } \\
\text { cell surface thus facilitating viral release }\end{array}$ & {$[202,204]$} \\
\hline Sunitinib & $\begin{array}{l}\text { Indolinone derivative; } \\
\text { tyrosine kinase receptor } \\
\text { inhibitor }\end{array}$ & Disrupts the actin network impairing viral endocytosis & {$[81,205]$} \\
\hline Suramin & $\begin{array}{l}\text { Polysulfonated } \\
\text { naphthylurea-based small } \\
\text { molecule }\end{array}$ & Interferes with viral binding and fusion & [206-209] \\
\hline Tilorone & $\begin{array}{l}\text { 2,7-Bis [2-(diethylamino) } \\
\text { ethoxy]-9H-fluoren-9-one; } \\
\text { amphiphilic cationic molecule }\end{array}$ & $\begin{array}{l}\text { Induces sulfated GAG storage; suppresses viral } \\
\text { replication by activating host innate immunity pathways }\end{array}$ & {$[81,139,210]$} \\
\hline
\end{tabular}


The therapeutics listed in Table 3 are FDA-approved drugs for the treatment of diseases other than SARS-CoV-2 infection, although an antiviral activity has been established for most of them [179-210].

Unfractionated (full length) and low-molecular-weight heparins are currently used for treating SARS-Cov-2-associated coagulopathy and thrombosis that contribute to the morbidity and mortality of the disease [154,211]. However, based on the co-receptor activity exerted by cell surface HS (the GAG class of which heparin is composed) in the entry and infectivity of SARS-CoV-2 discussed in the previous section, beyond anticoagulation, alternative beneficial mechanisms of action for heparin in patients with COVID-19 including direct SARS-CoV-2 antiviral activity have been proposed [179-183]. Heparin could serve as a competitive inhibitor for viral entry, thus reducing infectivity. The evidence that shorter heparins do not significantly bind S protein of SARS-CoV-2 [134] strongly suggests that the beneficial effects of unfractionated heparin could be due not only to its anticoagulant activity, but also to an antiviral action [130]. The antiviral activity of heparin against SARS-CoV-2 has been recently demonstrated in Vero E6 cells inoculated with a Dutch SARS-CoV-2 isolate [181]. In this study, heparin prevented SARS-CoV-2 infection and subsequent replication with a half-maximal inhibitory concentration $\left(\mathrm{IC}_{50}\right)$ below $125 \mu \mathrm{g} / \mathrm{mL}$. Although to date no clinical data linking heparin therapy to antiviral outcomes exist for COVID-19 patients, the use of heparin and other HS derivatives has the potential for future clinical applications $[182,183]$. The potential risks and off-target effects of heparin therapy, besides significant bleeding, still need to be identified due to the heterogeneous structure of unfractionated heparin. Heparin is formed by a mixture of distinct biologically derived HS chains that contain not only the pentasaccharide sequence necessary for antithrombin 3 activation (and thus anticoagulation), but also a wide variety of other non-anticoagulant sulfated sequences which allow heparin binding to several growth factors, potentially promoting both organ-protective [212,213] and organ-harmful [214,215] effects.

Heparin-binding peptides (HBPs) are non-anticoagulant natural or synthetic peptides able to antagonize the attachment of viruses to HSPGs [175]. Some of these peptides show antiviral activity toward human CMV, HSV-1, and HSV-2 [184,185]. Peptide-based therapeutics such as HBPs enter the cells through an endocytic pathway similar to that of viruses, but, unlike viruses, they cannot escape the endosomal/lysosomal system, and thus are sorted to lysosomes for degradation; this ability enables them to prevent viral egress and cell-to-cell spread of infection. To overcome this limitation, HBPs have been conjugated with a CRM-197 carrier protein, a nontoxic mutant of diphtheria toxin, which itself is an HBP with four heparin-binding domains [186], and it is able to escape the endosomal pathway to enter cytoplasm [187]. The HBP-CRM-197 conjugates enter the cells and by escaping the endosomal pathway bind cytoplasmic viruses, thus inhibiting viral replication and/or cell-to-cell transmission. Because an HBP-CRM-197 conjugate is already in a clinical trial for the treatment of systemic amyloidosis [188,189], it has been proposed as a potential therapeutic option for COVID-19 [175].

A high-throughput drug screen for inhibitors that block the SARS-CoV-2 entry pathway coupled to biochemical and mass spectrometry analyses resulted in the identification of two classes of drugs categorized based on their ability to bind heparin: BNTX, sunitinib, and tilorone with no affinity to heparin, and mitoxantrone with high affinity to heparin [81]. Among these drugs, tilorone and mitoxantrone are already used as broad-spectrum antiviral agents $[197,205,210]$. Of note, recent evidence demonstrated that when added to Vero cells prior to viral infection, tilorone exhibits antiviral activity against SARS-CoV-2 infection with an $\mathrm{IC}_{50}$ value of $4.09 \mu \mathrm{M}$ [139]. Lactoferrin, an iron-binding protein of the ferritin family secreted by glandular cells and present in most body fluids, is also considered a broad-spectrum antiviral agent, and it has been proposed as a potential preventive and adjunct treatment for COVID-19 [190-192]. The antiviral mechanisms of lactoferrin are based on its ability to bind either HSPGs on the host cell surface and, consequently, to reduce viral internalization into host 
cells [193,194], or to bind the viral particles to divert them from target cells [195]. Lactoferrin has shown antiviral activity in cell culture against several human coronaviruses, including CoV-OC43, CoV-229E, CoV-NL63, SARS-CoV, as well as SARS-CoV-2 [192], thus suggesting its potential use in SARS-CoV-2 infection. In addition to its oral bioavailability, the lack of immunogenicity, and the broad-spectrum antiviral activity, lactoferrin has also shown anti-inflammatory and immunomodulatory activities in severe viral infections [196], thus resulting in a promising drug candidate for COVID-19.

Among HS mimetics, there is muparfostat (PI 88), a d-mannose-based sulfated oligosaccharide mixture, which is used as adjuvant therapeutics for the treatment of hepatocarcinoma [198] and has shown antiviral activity towards poxvirus vaccinia virus (VACV) [199], HSV-1 and HSV-2 [200], DENV, and encephalitic flaviviruses [201]. Muparfostat inhibition of heparanase activity results in reduced viral infection and cell-tocell transmission [202]. The involvement of heparanase in the virus release might provide a novel route to effective anti-SARS-CoV-2 therapeutics as in the case of another HS mimetics, namely roneparstat (SST0001), already in a clinical trial as an anticancer agent (NCT01764880) [204]. Broad-spectrum antiviral activity has been demonstrated by dispirotripiperazine-based compounds (PDSTPs), small molecules with high binding affinity to HS [203], thus suggesting a potential use to inhibit SARS-CoV-2 entry into host cells. Suramin is the unique broad-spectrum antiviral repurposed drug that has already been shown to inhibit SARS-CoV-2 infection in in vitro cellular tools [206]. This polysulfonated naphthylurea-based small molecule has already been shown to efficiently inhibit infection from HCV [207], HSV-1 [208], Zika virus [209], and others. In Vero E6 cells and primary human airway epithelial cell culture model, suramin inhibited the progression of SARS-CoV-2 infection, possibly preventing the attachment or entry of the virus [206].

In addition to the repurposed drugs listed in Table 3, other approaches that target the HSPG biosynthetic machinery for the treatment of SARS-CoV-2 infection might include the use of synthetic xylosides $[9,20,216]$. These compounds, composed of a xylose and an aglycone group, compete with HSPG biosynthetic enzymes to bind HS, leading to reduced PG-bound HS and increased xyloside-bound HS. Synthetic xylosides are orally available, easily excreted by the organism, and are advantageous compared with syntheticor animal-derived HS for potential therapeutic applications because they utilize the host cell biosynthetic apparatus to assemble HS and are thus likely nonimmunogenic $[9,216]$. To date, the antiviral activity of xylosides remains unexplored. Another group of inhibitors of the HS synthesis is represented by analogs of genistein, a soy-derived isoflavone with structural similarity to $17 \beta$-estradiol, which inhibits GAG synthesis by affecting the epidermal growth factor (EGF)-dependent pathway [217]. These compounds have been proven to reduce GAG biosynthesis and derived disorders in human diseases such as mucopolysaccharidoses (MPSs), cancer, and rotavirus infection [218-220]. Furthermore, enzymatic methods employing mammalian heparanase and/or sulfatases to remove or to edit the sulfated domains of the HS chains have been explored to interfere with either the attachment of viruses to cell membrane HSPGs or the viral release and cellto-cell spread $[7,99,202,221,222]$. Interestingly, heparanase has been shown to affect the bioavailability of signaling molecules such as EGF, Akt, mitogen-activated protein kinase (MAPK)/extracellular signal-regulated kinase (ERK), and vascular endothelial growth factor (VEGF) that are known regulators of viral infections, thus playing an important role in the signaling pathways involved in viral pathogenesis [99]. Studies aimed to explore how heparanase regulates SARS-CoV-2 infection and interacts with the major pro-survival signaling pathways could provide insights to pave the way for novel therapies.

Finally, we recently developed an innovative HSPG-targeting strategy for the cure of some MPS subtypes, inherited human diseases characterized by the accumulation of an excess of the cell surface and extracellular HS leading to the loss of cellular functions, tissue damage, and organ dysfunctions [174]. The strategy, which we called substratemasking technology, is based on the use of NK1, a natural spliced variant of the hepatocyte growth factor/scatter factor (HGF/SF), which has a high binding affinity for the HS 
chains [223]. We demonstrated that the recombinant NK1 is able to bind the excess of accumulated HS and to reverse deregulated cellular processes in fibroblasts from MPSaffected patients [174]. NK1 treatment might also be effective against SARS-CoV-2 as well as all the other viruses that require HS binding for attachment and entry into host cells. On the other hand, growth factor receptors are involved in the pathogenesis of many viral infections, and thus they have emerged as potential therapeutic targets against viral diseases [224], including SARS-CoV-2 disease. Indeed, viruses may use growth factor receptors not only to attach to the host cell surface and subsequently internalize into the host cell, but also to target receptor signaling to their replication. To mask HS chains on the host cell surface thus preventing virus attachment, the HGF truncated peptide NK1 could interact with the tyrosine kinase receptor Met, thus affecting the downstream signaling pathways essential for the viral replication. Studies are in progress in our laboratory to evaluate the efficacy of the recombinant NK1 to prevent SARS-CoV-2 infection in vitro, and its molecular mechanism of action.

\section{Concluding Remarks}

The ubiquitously expressed HSPGs play key roles in the pathogenesis of many human viral infections. They not only facilitate viral attachment to the target cells, but may also be involved in the pathways responsible for the internalization, intracellular trafficking, and release of the viral particles. Among the viruses that exploit HSPGs to infect target cells, SARS-CoV-2 has recently raised great public health concern due to its pandemic spread. A consistent amount of data supports the dependence of SARS-CoV-2 on HSPGs for an efficient infection. These data suggest that HSPGs serve as a co-receptor for the viral S protein interaction with the ACE2 entry receptor, thus contributing to viral internalization $[66,109,110,129,132,225]$. However, as HSPGs have been recognized as key inflammatory mediators in a variety of settings $[6,226,227]$, they could play an important role in the regulation of the host cell immune response to SARS-CoV-2 infection. Thus, it will be intriguing to establish whether and how HSPGs affect the exuberant inflammatory response associated with the severe forms of COVID-19 [228].

It has been widely established that SARS-CoV-2 infection not only involves the respiratory tract but also other organs including the gut, liver, kidney, heart, and pancreas [141-145]. On the other hand, evidence has revealed that the male sex is a risk factor for a more severe disease, including death [172]. In addition, severe disease outcomes have been reported for older people, with young and healthy adults showing a different disease tropism and less severe disease [173]. The precise structural features of HSPGs among the tremendous variety of sulfated HS chains as well as the distinct expression of HSPG synthetic and modifying enzymes within different tissues and organs might contribute to accounting for the differential SARS-CoV-2 tropism, and the distinct susceptibility to infection of different human populations remains an open issue.

Evidence regarding the fundamental roles of the HSPGs in the SARS-CoV-2 pathogenicity has not only provided a better understanding of the virus's biology and the molecular mechanisms of infection, but has also allowed researchers to identify HSPG-targeted therapies as effective intervention strategies. The potential candidates include HSPG-targeting therapeutics that have already been shown to be effective for the cure of some human diseases including infections from viruses other than SARS-CoV-2. While all of these drugs may represent promising therapeutic options against SARS-CoV-2 infection in humans, specific in vitro studies and in vivo clinical trials are still lacking for most of them. Additional efforts in such a direction might aid the development of antiviral drugs that could be effective for SARS-CoV-2 as well as unforeseeable viruses.

Author Contributions: V.D.P.: selected the subject material, collected and analyzed the literature, and wrote the paper. M.S.Q.: collected and analyzed the literature and shared in the writing; S.T.: collected and analyzed the literature and shared in the writing; L.A.: collected and analyzed the literature and shared in the writing. L.M.P.: provided intellectual input, analyzed the literature 
and participated in the writing. All authors have read and agreed to the published version of the manuscript.

Funding: This research was funded by University of Naples Federico II, Naples, Italy, grant FRA 2020 LINEA B "ChromPred" to L.M.P. The funder has no role in the writing of this review article. The APC was funded by FRA 2020 LINEA B “ChromPred" to L.M.P.

Conflicts of Interest: L.M.P. has granted a patent for the use of HGF and its variants for the treatment of mucopolysaccharidoses. The authors declare no additional competing financial interest.

\section{References}

1. Sarrazin, S.; Lamanna, W.C.; Esko, J.D. Heparan sulfate proteoglycans. Cold Spring Harb. Perspect. Biol. 2011, 3, a004952. [CrossRef] [PubMed]

2. Iozzo, R.V.; Schaefer, L. Proteoglycan form and function: A comprehensive nomenclature of proteoglycans. Matrix Biol. 2015, 42, 11-55. [CrossRef] [PubMed]

3. Li, J.-P.; Kusche-Gullberg, M. Heparan sulfate: Biosynthesis, structure, and function. Int. Rev. Cell Mol. Biol. $2016,325,215-273$.

4. Annaval, T.; Wild, R.; Crétinon, Y.; Sadir, R.; Vivès, R.R.; Lortat-Jacob, H. Heparan sulfate proteoglycans biosynthesis and post synthesis mechanisms combine few enzymes and few core proteins to generate extensive structural and functional diversity. Molecules 2020, 25, 4215. [CrossRef] [PubMed]

5. Pasquale, V.D.; Moles, A.; Pavone, L.M. Cathepsins in the pathophysiology of mucopolysaccharidoses: New perspectives for therapy. Cells 2020, 9, 979. [CrossRef]

6. Khanna, M.; Parish, C.R. Heparanase: Historical aspects and future perspectives. Adv. Exp. Med. Biol. 2020, 1221, 71-96.

7. Rangarajan, S.; Richter, J.R.; Richter, R.P.; Bandari, S.K.; Tripathi, K.; Vlodavsky, I.; Sanderson, R.D. Heparanase-enhanced shedding of syndecan-1 and its role in driving disease pathogenesis and progression. J. Histochem. Cytochem. 2020, 68, 823-840. [CrossRef]

8. Nagamine, S.; Tamba, M.; Ishimine, H.; Araki, K.; Shiomi, K.; Okada, T.; Ohto, T.; Kunita, S.; Takahashi, S.; Wismans, R.G.P.; et al. Organ-specific sulfation patterns of heparan sulfate generated by extracellular sulfatases Sulf1 and Sulf2 in mice. J. Biol. Chem. 2012, 287, 9579-9590. [CrossRef]

9. Karamanos, N.K.; Piperigkou, Z.; Theocharis, A.D.; Watanabe, H.; Franchi, M.; Baud, S.; Brézillon, S.; Götte, M.; Passi, A.; Vigetti, D.; et al. Proteoglycan chemical diversity drives multifunctional cell regulation and therapeutics. Chem. Rev. 2018, 118, 9152-9232. [CrossRef]

10. Afratis, N.A.; Nikitovic, D.; Multhaupt, H.A.B.; Theocharis, A.D.; Couchman, J.R.; Karamanos, N.K. Syndecans—Key regulators of cell signaling and biological functions. FEBS J. 2017, 284, 27-41. [CrossRef]

11. Yu, C.; Griffiths, L.R.; Haupt, L.M. Exploiting heparan sulfate proteoglycans in human neurogenesis-Controlling lineage specification and fate. Front. Integr. Neurosci. 2017, 11, 28. [CrossRef] [PubMed]

12. Schwartz, N.B.; Domowicz, M.S. Proteoglycans in brain development and pathogenesis. FEBS Lett. 2018, 592, $3791-3805$. [CrossRef] [PubMed]

13. O'Callaghan, P.; Zhang, X.; Li, J.-P. Heparan sulfate proteoglycans as relays of neuroinflammation. J. Histochem. Cytochem. 2018, 66, 305-319. [CrossRef] [PubMed]

14. Pasquale, V.D.; Pavone, L.M. Heparan sulfate proteoglycans: The sweet side of development turns sour in mucopolysaccharidoses. Biochim. Biophys. Acta Mol. Basis Dis. 2019, 1865, 165539. [CrossRef] [PubMed]

15. Pasquale, V.D.; Pavone, L.M. Heparan sulfate proteoglycan signaling in tumor microenvironment. Int. J. Mol. Sci. 2020, 21, 6588. [CrossRef]

16. Hassan, N.; Greve, B.; Espinoza-Sánchez, N.A.; Götte, M. Cell-surface heparan sulfate proteoglycans as multifunctional integrators of signaling in cancer. Cell Signal. 2021, 77, 109822. [CrossRef]

17. Li, J.-P.; Zhang, X. Implications of heparan sulfate and heparanase in amyloid diseases. Adv. Exp. Med. Biol. 2020, 1221, 631-645.

18. Billings, P.C.; Pacifici, M. Interactions of signaling proteins, growth factors and other proteins with heparan sulfate: Mechanisms and mysteries. Connect. Tissue Res. 2015, 56, 272-280. [CrossRef]

19. Xie, M.; Li, J. Heparan sulfate proteoglycan-A common receptor for diverse cytokines. Cell Signal. 2019, 54, 115-121. [CrossRef] [PubMed]

20. Weiss, R.J.; Esko, J.D.; Tor, Y. Targeting heparin and heparan sulfate protein interactions. Org. Biomol. Chem. 2017, 15, 5656-5668. [CrossRef]

21. Christianson, H.C.; Belting, M. Heparan sulfate proteoglycan as a cell-surface endocytosis receptor. Matrix Biol. 2014, 35, 51-55. [CrossRef]

22. Hudák, A.; Kusz, E.; Domonkos, I.; Jósvay, K.; Kodamullil, A.T.; Szilák, L.; Hofmann-Apitius, M.; Letoha, T. Contribution of syndecans to cellular uptake and fibrillation of $\alpha$-synuclein and tau. Sci. Rep. 2019, 9, 16543. [CrossRef]

23. Cerezo-Magaña, M.; Bång-Rudenstam, A.; Belting, M. The pleiotropic role of proteoglycans in extracellular vesicle mediated communication in the tumor microenvironment. Semin. Cancer Biol. 2020, 62, 99-107. [CrossRef] [PubMed]

24. Kamhi, E.; Joo, E.J.; Dordick, J.S.; Linhardt, R.J. Glycosaminoglycans in infectious disease. Biol. Rev. 2013, 88, 928-943. [CrossRef] [PubMed] 
25. Cagno, V.; Tseligka, E.D.; Jones, S.T.; Tapparel, C. Heparan sulfate proteoglycans and viral attachment: True receptors or adaptation bias? Viruses 2019, 11, 596. [CrossRef]

26. Hofmann, H.; Pyrc, K.; Van der Hoek, L.; Geier, M.; Berkhout, B.; Pohlmann, S. Human coronavirus NL63 employs the severe acute respiratory syndrome coronavirus receptor for cellular entry. Proc. Natl. Acad. Sci. USA 2005, 102, 7988-7993. [CrossRef]

27. Milewska, A.; Zarebski, M.; Nowak, P.; Stozek, K.; Potempa, J.; Pyrc, K. Human coronavirus NL63 utilizes heparan sulfate proteoglycans for attachment to target cells. J. Virol. 2014, 88, 13221-13230. [CrossRef]

28. Naskalska, A.; Dabrowska, A.; Szczepanski, A.; Milewska, A.; Jasik, K.P.; Pyrc, K. Membrane protein of human coronavirus NL63 is responsible for interaction with the adhesion receptor. J. Virol. 2019, 93, e00355-e00419. [CrossRef]

29. Cruz-Oliveira, C.; Freire, J.M.; Conceição, T.M.; Higa, L.M.; Castanho, M.A.R.B.; Poian, A.T.D. Receptors and routes of dengue virus entry into the host cells. FEMS Microbiol. Rev. 2015, 39, 155-170. [CrossRef] [PubMed]

30. Perera, R.; Kuhn, R.J. Structural proteomics of dengue virus. Curr. Opin. Microbiol. 2008, 11, 369-377. [CrossRef]

31. Liu, P.; Ridilla, M.; Patel, P.; Betts, L.; Gallichotte, E.; Shahidi, L.; Thompson, N.L.; Jacobson, K. Beyond attachment: Roles of DC-SIGN in dengue virus infection. Traffic 2017, 18, 218-231. [CrossRef] [PubMed]

32. Kobayashi, K.; Koike, S. Cellular receptors for enterovirus A71. J. Biomed. Sci. 2020, 27, 23. [CrossRef] [PubMed]

33. Spear, P.G. Herpes simplex virus: Receptors and ligands for cell entry. Cell. Microbiol. 2004, 6, 401-410. [CrossRef] [PubMed]

34. Bacsa, S.; Karasneh, G.; Dosa, S.; Liu, J.; Valyi-Nagy, T.; Shukla, D. Syndecan-1 and syndecan-2 play key roles in herpes simplex virus type-1 infection. J. Gen. Virol. 2011, 92, 733-743. [CrossRef] [PubMed]

35. Gianni, T.; Salvioli, S.; Chesnokova, L.S.; Hutt-Fletcher, L.M.; Campadelli-Fiume, G. $\alpha \mathrm{v} \beta 6$ - and $\alpha \mathrm{v} \beta 8$-integrins serve as interchangeable receptors for HSV gH/gL to promote endocytosis and activation of membrane fusion. PLoS Pathog 2013, 9, e1003806. [CrossRef]

36. Madavaraju, K.; Koganti, R.; Volety, I.; Yadavalli, T.; Shukla, D. Herpes simplex virus cell entry mechanisms: An update. Front. Cell. Infect. Microbiol. 2021, 10, 617578. [CrossRef] [PubMed]

37. Parseval, A.D.; Bobardt, M.D.; Chatterji, A.; Chatterji, U.; Elder, J.H.; David, G.; Zolla-Pazner, S.; Farzan, M.; Lee, T.-H.; Gallay, P.A. A highly conserved arginine in gp120 governs HIV-1 binding to both syndecans and CCR5 via sulfated motifs. J. Biol. Chem. 2005, 280, 39493-39504. [CrossRef]

38. Pomin, V.H.; Bezerra, F.F.; Soares, P.A.G. Sulfated glycans in HIV infection and therapy. Curr. Pharm. Des. 2017, 23, 3405-3414. [CrossRef] [PubMed]

39. Saphire, A.C.S.; Bobardt, M.D.; Gallay, P.A. Human immunodeficiency virus type 1 hijacks host cyclophilin A for its attachment to target cells. Immunol. Res. 2000, 21, 211-218. [CrossRef]

40. Sureau, C.; Salisse, J. A conformational heparan sulfate binding site essential to infectivity overlaps with the conserved hepatitis B virus A-determinant. Hepatology 2013, 57, 985-994. [CrossRef]

41. Hayes, C.N.; Zhang, Y.; Makokha, G.N.; Hasan, M.Z.; Omokoko, M.D.; Chayama, K. Early events in hepatitis B virus infection: From the cell surface to the nucleus. J. Gastroenterol. Hepatol. 2016, 31, 302-309. [CrossRef]

42. Verrier, E.R.; Colpitts, C.C.; Bach, C.; Heydmann, L.; Weiss, A.; Renaud, M.; Durand, S.C.; Habersetzer, F.; Durantel, D.; AbouJaoudé, G.; et al. A targeted functional RNA interference screen uncovers glypican 5 as an entry factor for hepatitis B and D viruses. Hepatology 2016, 63, 35-48. [CrossRef]

43. Herrscher, C.; Roingeard, P.; Blanchard, E. Hepatitis B virus entry into cells. Cells 2020, 9, 1486. [CrossRef]

44. Barth, H.; Schnober, E.K.; Zhang, F.; Linhardt, R.J.; Depla, E.; Boson, B.; Cosset, F.-L.; Patel, A.H.; Blum, H.E.; Baumert, T.F. Viral and cellular determinants of the hepatitis C virus envelope-heparan sulfateInteraction. J. Virol. 2006, 80, 10579-10590. [CrossRef]

45. Shi, Q.; Jiang, J.; Luo, G. Syndecan-1 serves as the major receptor for attachment of hepatitis C virus to the surfaces of hepatocytes. J. Virol. 2013, 87, 6866-6875. [CrossRef] [PubMed]

46. Lefèvre, M.; Felmlee, D.J.; Parnot, M.; Baumert, T.F.; Schuster, C. Syndecan 4 is involved in mediating HCV entry through interaction with lipoviral particle-associated apolipoprotein E. PLoS ONE 2014, 9, e95550. [CrossRef] [PubMed]

47. Xu, Y.; Martinez, P.; Séron, K.; Luo, G.; Allain, F.; Dubuisson, J.; Belouzard, S. Characterization of hepatitis C virus interaction with heparan sulfate proteoglycans. J. Virol. 2015, 89, 3846-3858. [CrossRef] [PubMed]

48. Wang, J.; Qiao, L.; Hou, Z.; Luo, G. TIM-1 promotes hepatitis C virus cell attachment and infection. J. Virol. 2017, 91, e01583-e01616. [CrossRef]

49. Kalia, M.; Chandra, V.; Rahman, S.A.; Sehgal, D.; Jameel, S. Heparan sulfate proteoglycans are required for cellular binding of the hepatitis E virus ORF2 capsid protein and for viral infection. J. Virol. 2009, 83, 12714-12724. [CrossRef] [PubMed]

50. Wißing, M.H.; Brüggemann, Y.; Steinmann, E.; Todt, D. Virus-host cell interplay during hepatitis E virus infection. Trends Microbiol. 2021, 29, 309-319. [CrossRef]

51. Raff, A.B.; Woodham, A.W.; Raff, L.M.; Skeate, J.G.; Yan, L.; Silva, D.M.D.; Schelhaas, M.; Kast, W.M. The evolving field of human papillomavirus receptor research: A review of binding and entry. J. Virol. 2013, 87, 6062-6072. [CrossRef]

52. Richards, K.F.; Bienkowska-Haba, M.; Dasgupta, J.; Chen, X.S.; Sapp, M. Multiple heparan sulfate binding site engagements are required for the infectious entry of human papillomavirus type. J. Virol. 2013, 87, 11426-11437. [CrossRef]

53. Surviladze, Z.; Sterkand, R.T.; Ozbun, M.A. Interaction of human papillomavirus type 16 particles with heparan sulfate and syndecan-1 molecules in the keratinocyte extracellular matrix plays an active role in infection. J. Gen. Virol. 2015, 96, 2232-2241. [CrossRef] [PubMed] 
54. Becker, M.; Greune, L.; Schmidt, M.A.; Schelhaas, M. Extracellular conformational changes in the capsid of human papillomaviruses contribute to asynchronous uptake into host cells. J. Virol. 2018, 92, e02106-e02117. [CrossRef] [PubMed]

55. Schowalter, R.M.; Pastrana, D.V.; Buck, C.B. Glycosaminoglycans and sialylated glycans sequentially facilitate merkel cell polyomavirus infectious entry. PLoS Pathog 2011, 7, e1002161. [CrossRef] [PubMed]

56. Bayer, N.J.; Januliene, D.; Zocher, G.; Stehle, T.; Moeller, A.; Blaum, B.S. Structure of merkel cell polyomavirus capsid and interaction with its glycosaminoglycan attachment receptor. J. Virol. 2020, 94, e01664-e01719. [CrossRef]

57. Chang, A.; Masante, C.; Buchholz, U.J.; Dutch, R.E. Human metapneumovirus (HMPV) binding and infection are mediated by interactions between the HMPV fusion protein and heparan sulfate. J. Virol. 2012, 86, 3230-3243. [CrossRef]

58. Klimyte, E.M.; Smith, S.E.; Oreste, P.; Lembo, D.; Dutch, R.E. Inhibition of human metapneumovirus binding to heparan sulfate blocks infection in human lung cells and airway tissues. J. Virol. 2016, 90, 9237-9250. [CrossRef]

59. Sasaki, M.; Anindita, P.D.; Ito, N.; Sugiyama, M.; Carr, M.; Fukuhara, H.; Ose, T.; Maenaka, K.; Takada, A.; Hall, W.W.; et al. The role of heparan sulfate proteoglycans as an attachment factor for rabies virus entry and infection. J. Infect. Dis. 2018, 217, 1740-1749. [CrossRef]

60. Wang, J.; Wang, Z.; Liu, R.; Shuai, L.; Wang, X.; Luo, J.; Wang, C.; Chen, W.; Wang, X.; Ge, J.; et al. Metabotropic glutamate receptor subtype 2 is a cellular receptor for rabies virus. PLoS Pathog 2018, 14, e1007189. [CrossRef]

61. Guo, Y.; Duan, M.; Wang, X.; Gao, J.; Guan, Z.; Zhang, M. Early events in rabies virus infection-Attachment, entry, and intracellular trafficking. Virus Res. 2019, 263, 217-225. [CrossRef]

62. Feldman, S.A.; Audet, S.; Beeler, J.A. The fusion glycoprotein of human respiratory syncytial virus facilitates virus attachment and infectivity via an interaction with cellular heparan sulfate. J. Virol. 2000, 74, 6442-6447. [CrossRef] [PubMed]

63. Hallak, L.K.; Kwilas, S.A.; Peeples, M.E. Interaction between respiratory syncytial virus and glycosaminoglycans, including heparan sulfate. Methods Mol. Biol. 2007, 379, 15-34. [PubMed]

64. Tayyari, F.; Marchant, D.; Moraes, T.J.; Duan, W.; Mastrangelo, P.; Hegele, R.G. Identification of nucleolin as a cellular receptor for human respiratory syncytial virus. Nat. Med. 2011, 17, 1132-1135. [CrossRef] [PubMed]

65. McLellan, J.S.; Ray, W.C.; Peeples, M.E. Structure and function of respiratory syncytial virus surface glycoproteins. Curr. Top. Microbiol. Immunol. 2013, 372, 83-104. [PubMed]

66. Clausen, T.M.; Sandoval, D.R.; Spliid, C.B.; Pihl, J.; Perrett, H.R.; Painter, C.D.; Narayanan, A.; Majowicz, S.A.; Kwong, E.M.; McVicar, R.N.; et al. SARS-CoV-2 infection depends on cellular heparan sulfate and ACE2. Cell 2020, 183, 1043-1057.e15. [CrossRef] [PubMed]

67. Cantuti-Castelvetri, L.; Ojha, R.; Pedro, L.D.; Djannatian, M.; Franz, J.; Kuivanen, S.; Van der Meer, F.; Kallio, K.; Kaya, T.; Anastasina, M.; et al. Neuropilin-1 facilitates SARS-CoV-2 cell entry and infectivity. Science 2020, 370, 856-860. [CrossRef]

68. Daly, J.L.; Simonetti, B.; Klein, K.; Chen, K.-E.; Williamson, M.K.; Antón-Plágaro, C.; Shoemark, D.K.; Simón-Gracia, L.; Bauer, M.; Hollandi, R.; et al. Neuropilin-1 is a host factor for SARS-CoV-2 infection. Science 2020, 370, 861-865. [CrossRef] [PubMed]

69. Wang, S.; Qiu, Z.; Hou, Y.; Deng, X.; Xu, W.; Zheng, T.; Wu, P.; Xie, S.; Bian, W.; Zhang, C.; et al. AXL is a candidate receptor for SARS-CoV-2 that promotes infection of pulmonary and bronchial epithelial cells. Cell Res. 2021, 31, 126-140. [CrossRef]

70. Tiwari, V.; Clement, C.; Xu, D.; Valyi-Nagy, T.; Yue, B.Y.J.T.; Liu, J.; Shukla, D. Role for 3-O-sulfated heparan sulfate as the receptor for herpes simplex virus type 1 entry into primary human corneal fibroblasts. J. Virol. 2006, 80, 8970-8980. [CrossRef]

71. Choudhary, S.; Marquez, M.; Alencastro, F.; Spors, F.; Zhao, Y.; Tiwari, V. Herpes simplex virus type-1 (HSV-1) entry into human mesenchymal stem cells is heavily dependent on heparan sulfate. J. Biomed. Biotechnol. 2011, 2011, 1-11. [CrossRef] [PubMed]

72. Tiwari, V.; Tarbutton, M.; Shukla, D. Diversity of heparan sulfate and HSV entry: Basic understanding and treatment strategies. Molecules 2015, 20, 2707-2727. [CrossRef] [PubMed]

73. Akhtar, J.; Shukla, D. Viral entry mechanisms: Cellular and viral mediators of herpes simplex virus entry. FEBS J. 2009, 276, 7228-7236. [CrossRef]

74. Mercer, J.; Schelhaas, M.; Helenius, A. Virus entry by endocytosis. Annu. Rev. Biochem. 2010, 79, 803-833. [CrossRef] [PubMed]

75. Somiya, M.; Liu, Q.; Yoshimoto, N.; Iijima, M.; Tatematsu, K.; Nakai, T.; Okajima, T.; Kuroki, K.; Ueda, K.; Kuroda, S. Cellular uptake of hepatitis B virus envelope $\mathrm{L}$ particles is independent of sodium taurocholate cotransporting polypeptide, but dependent on heparan sulfate proteoglycan. Virology 2016, 497, 23-32. [CrossRef]

76. Chen, B. Molecular mechanism of HIV-1 entry. Trends Microbiol. 2019, 27, 878-891. [CrossRef] [PubMed]

77. Bugatti, A.; Urbinati, C.; Ravelli, C.; Clercq, E.D.; Liekens, S.; Rusnati, M. Heparin-mimicking sulfonic acid polymers as multitarget inhibitors of human immunodeficiency virus type 1 tat and gp120 proteins. Antimicrob. Agents Chemother. 2007, 51, 2337-2345. [CrossRef]

78. Zhang, Q.; Chen, C.Z.; Swaroop, M.; Xu, M.; Wang, L.; Lee, J.; Wang, A.Q.; Pradhan, M.; Hagen, N.; Chen, L.; et al. Heparan sulfate assists SARS-CoV-2 in cell entry and can be targeted by approved drugs in vitro. Cell Discov. 2020, 6, 80. [CrossRef]

79. Vlasak, M.; Goesler, I.; Blaas, D. Human rhinovirus type 89 variants use heparan sulfate proteoglycan for cell attachment. J. Virol. 2005, 79, 5963-5970. [CrossRef] [PubMed]

80. Bochkov, Y.A.; Watters, K.; Basnet, S.; Sijapati, S.; Hill, M.; Palmenberg, A.C.; Gern, J.E. Mutations in VP1 and 3A proteins improve binding and replication of rhinovirus C15 in HeLa-E8 cells. Virology 2016, 499, 350-360. [CrossRef]

81. Zautner, A.E.; Körner, U.; Henke, A.; Badorff, C.; Schmidtke, M. Heparan sulfates and coxsackievirus-adenovirus receptor: Each one mediates coxsackievirus B3 PD infection. J. Virol. 2003, 77, 10071-10077. [CrossRef] 
82. Klimstra, W.B.; Ryman, K.D.; Johnston, R.E. Adaptation of Sindbis virus to BHK cells selects for use of heparan sulfate as an attachment receptor. J. Virol. 1998, 72, 7357-7366. [CrossRef]

83. Bear, J.S.; Byrnes, A.P.; Griffin, D.E. Heparin-binding and patterns of virulence for two recombinant strains of Sindbis virus. Virology 2006, 347, 183-190. [CrossRef]

84. Holmes, A.C.; Basore, K.; Fremont, D.H.; Diamond, M.S. A molecular understanding of alphavirus entry. PLoS Pathog 2020, 16, e1008876. [CrossRef]

85. Mandl, C.W.; Kroschewski, H.; Allison, S.L.; Kofler, R.; Holzmann, H.; Meixner, T.; Heinz, F.X. Adaptation of tick-borne encephalitis virus to BHK-21 cells results in the formation of multiple heparan sulfate binding sites in the envelope protein and attenuation in vivo. J. Virol. 2001, 75, 5627-5637. [CrossRef]

86. Kozlovskaya, L.I.; Osolodkin, D.I.; Shevtsova, A.S.; Romanova, L.I.; Rogova, Y.V.; Dzhivanian, T.I.; Lyapustin, V.N.; Pivanova, G.P.; Gmyl, A.P.; Palyulin, V.A.; et al. GAG-binding variants of tick-borne encephalitis virus. Virology 2010, 398, 262-272. [CrossRef]

87. Tseligka, E.D.; Sobo, K.; Stoppini, L.; Cagno, V.; Abdul, F.; Piuz, I.; Meylan, P.; Huang, S.; Constant, S.; Tapparel, C. A VP1 mutation acquired during an enterovirus 71 disseminated infection confers heparan sulfate binding ability and modulates ex vivo tropism. PLoS Pathog 2018, 14, e1007190. [CrossRef] [PubMed]

88. Gorelik, L.; Reid, C.; Testa, M.; Brickelmaier, M.; Bossolasco, S.; Pazzi, A.; Bestetti, A.; Carmillo, P.; Wilson, E.; McAuliffe, M.; et al. Progressive multifocal leukoencephalopathy (PML) development is associated with mutations in JC virus capsid protein VP1 that change its receptor specificity. J. Infect. Dis. 2011, 204, 103-114. [CrossRef] [PubMed]

89. Baric, R.S. Emergence of a highly fit SARS-CoV-2 variant. N. Engl. J. Med. 2020, 383, 2684-2686. [CrossRef] [PubMed]

90. Korber, B.; Fischer, W.M.; Gnanakaran, S.; Yoon, H.; Theiler, J.; Abfalterer, W.; Hengartner, N.; Giorgi, E.E.; Bhattacharya, T.; Foley, B.; et al. Tracking changes in SARS-CoV-2 spike: Evidence that D614G increases infectivity of the COVID-19 virus. Cell 2020, 182, 812-827.e19. [CrossRef]

91. Volz, E.; Hill, V.; McCrone, J.T.; Price, A.; Jorgensen, D.; O’Toole, Á.; Southgate, J.; Johnson, R.; Jackson, B.; Nascimento, F.F.; et al. Evaluating the effects of SARS-CoV-2 spike mutation D614G on transmissibility and pathogenicity. Cell 2021, 184, 64-75.e11. [CrossRef]

92. Kobayashi, K.; Sudaka, Y.; Takashino, A.; Imura, A.; Fujii, K.; Koike, S. Amino acid variation at VP1-145 of enterovirus 71 determines attachment receptor usage and neurovirulence in human scavenger receptor B2 transgenic mice. J. Virol. 2018, 92, e00681-e00718. [CrossRef] [PubMed]

93. Lee, E.; Wright, P.J.; Davidson, A.; Lobigs, M. Virulence attenuation of Dengue virus due to augmented glycosaminoglycanbinding affinity and restriction in extraneural dissemination. J. Gen. Virol. 2006, 87, 2791-2801. [CrossRef] [PubMed]

94. Helmová, R.; Hönig, V.; Tykalová, H.; Palus, M.; Bell-Sakyi, L.; Grubhoffer, L. Tick-borne encephalitis virus adaptation in different host environments and existence of quasispecies. Viruses 2020, 12, 902. [CrossRef] [PubMed]

95. Sa-Carvalho, D.; Rieder, E.; Baxt, B.; Rodarte, R.; Tanuri, A.; Mason, P.W. Tissue culture adaptation of foot-and-mouth disease virus selects viruses that bind to heparin and are attenuated in cattle. J. Virol. 1997, 71, 5115-5123. [CrossRef]

96. Sherer, N.M.; Jin, J.; Mothes, W. Directional spread of surface-associated retroviruses regulated by differential virus-cell interactions. J. Virol. 2010, 84, 3248-3258. [CrossRef] [PubMed]

97. Connell, B.J.; Lortat-Jacob, H. Human immunodeficiency virus and heparan sulfate: From attachment to entry inhibition. Front. Immunol. 2013, 4, 385. [CrossRef] [PubMed]

98. Bobardt, M.D.; Saphire, A.C.; Hung, H.-C.; Yu, X.; Van der Schueren, B.; Zhang, Z.; David, G.; Gallay, P.A. Syndecan captures, protects, and transmits HIV to T lymphocytes. Immunity 2003, 18, 27-39. [CrossRef]

99. Kaltenbach, D.D.; Jaishankar, D.; Hao, M.; Beer, J.C.; Volin, M.V.; Desai, U.R.; Tiwari, V. Sulfotransferase and heparanase: Remodeling engines in promoting virus infection and disease development. Front. Pharmacol. 2018, 9, 1315. [CrossRef] [PubMed]

100. Baldwin, J.; Maus, E.; Zanotti, B.; Volin, M.V.; Tandon, R.; Shukla, D.; Tiwari, V. A Role for 3-O-sulfated heparan sulfate in promoting human cytomegalovirus infection in human iris cells. J. Virol. 2015, 89, 5185-5192. [CrossRef]

101. Zautner, A.E.; Jahn, B.; Hammerschmidt, E.; Wutzler, P.; Schmidtke, M. N- and 6-O-sulfated heparan sulfates mediate internalization of coxsackievirus B3 variant PD into CHO-K1 cells. J. Virol. 2006, 80, 6629-6636. [CrossRef] [PubMed]

102. Puerta-Guardo, H.; Glasner, D.R.; Harris, E. Dengue virus NS1 disrupts the endothelial glycocalyx, leading to hyperpermeability. PLoS Pathog 2016, 12, e1005738. [CrossRef] [PubMed]

103. Glasner, D.R.; Puerta-Guardo, H.; Beatty, P.R.; Harris, E. The good, the bad, and the shocking: The multiple roles of Dengue virus nonstructural protein 1 in protection and pathogenesis. Annu. Rev. Virol. 2018, 5, 227-253. [CrossRef]

104. Hadigal, S.; Koganti, R.; Yadavalli, T.; Agelidis, A.; Suryawanshi, R.; Shukla, D. Heparanase-regulated syndecan-1 shedding facilitates herpes simplex virus 1 egress. J. Virol. 2019, 94, e01672-e01719. [CrossRef]

105. Hadigal, S.R.; Agelidis, A.M.; Karasneh, G.A.; Antoine, T.E.; Yakoub, A.M.; Ramani, V.C.; Djalilian, A.R.; Sanderson, R.D.; Shukla, D. Heparanase is a host enzyme required for herpes simplex virus-1 release from cells. Nat. Commun. 2015, 6, 6985. [CrossRef]

106. Zhang, Z.; Liu, X.; Chen, J.; Su, H.; Luo, Q.; Ye, J.; Tang, N.; Zhang, W.; Chen, W.; Ko, B.C.B.; et al. Heparin sulphate d-glucosaminyl 3-O-sulfotransferase 3B1 plays a role in HBV replication. Virology 2010, 406, 280-285. [CrossRef]

107. Ozbun, M.A. Extracellular events impacting human papillomavirus infections: Epithelial wounding to cell signaling involved in virus entry. Papillomavirus Res. 2019, 7, 188-192. [CrossRef] [PubMed]

108. Dong, L.-Q.; Wang, X.-Q.; Guo, Y.-N.; Wu, J.; Li, S.; Yu, P.; Wang, Z. HS N-sulfation and iduronic acids play an important role in the infection of respiratory syncytial virus in vitro. Eur. Rev. Med. Pharmacol. Sci. 2013, 17, 1864-1868. [PubMed] 
109. Tiwari, V.; Tandon, R.; Sankaranarayanan, N.V.; Beer, J.C.; Kohlmeir, E.K.; Swanson-Mungerson, M.; Desai, U.R. Preferential recognition and antagonism of SARS-CoV-2 spike glycoprotein binding to 3-O-sulfated heparan sulfate. bioRxiv 2020, 1. [CrossRef]

110. Buijsers, B.; Yanginlar, C.; Nooijer, A.D.; Grondman, I.; Maciej-Hulme, M.L.; Jonkman, I.; Janssen, N.A.F.; Rother, N.; Graaf, M.D.; Pickkers, P.; et al. Increased plasma heparanase activity in COVID-19 patients. Front. Immunol. 2020, 11, 2572. [CrossRef]

111. Cui, J.; Li, F.; Shi, Z.-L. Origin and evolution of pathogenic coronaviruses. Nat. Rev. Microbiol. 2019, 17, 181-192. [CrossRef]

112. Krishnamoorthy, S.; Swain, B.; Verma, R.S.; Gunthe, S.S. SARS-CoV, MERS-CoV, and 2019-nCoV viruses: An overview of origin, evolution, and genetic variations. VirusDisease 2020, 31, 411-423. [CrossRef]

113. Neuman, B.W.; Buchmeier, M.J. Supramolecular architecture of the coronavirus particle. Adv. Virus Res. 2016, 96, 1-27. [PubMed]

114. Michel, C.J.; Mayer, C.; Poch, O.; Thompson, J.D. Characterization of accessory genes in coronavirus genomes. Virol. J. 2020, 17, 131. [CrossRef] [PubMed]

115. Li, Z.; Tomlinson, A.C.; Wong, A.H.; Zhou, D.; Desforges, M.; Talbot, P.J.; Benlekbir, S.; Rubinstein, J.L.; Rini, J.M. The human coronavirus HCoV-229E S-protein structure and receptor binding. eLife 2019, 8, e51230. [CrossRef]

116. Wang, N.; Shi, X.; Jiang, L.; Zhang, S.; Wang, D.; Tong, P.; Guo, D.; Fu, L.; Cui, Y.; Liu, X.; et al. Structure of MERS-CoV spike receptor-binding domain complexed with human receptor DPP4. Cell Res. 2013, 23, 986-993. [CrossRef] [PubMed]

117. Yuan, M.; Wu, N.C.; Zhu, X.; Lee, C.-C.D.; So, R.T.Y.; Lv, H.; Mok, C.K.P.; Wilson, I.A. A highly conserved cryptic epitope in the receptor binding domains of SARS-CoV-2 and SARS-CoV. Science 2020, 368, 630-633. [CrossRef]

118. To, K.; Tong, J.H.; Chan, P.K.; Au, F.W.; Chim, S.S.; Chan, K.A.; Cheung, J.L.; Liu, E.Y.; Tse, G.M.; Lo, A.W.; et al. Tissue and cellular tropism of the coronavirus associated with severe acute respiratory syndrome: An in-situ hybridization study of fatal cases. J. Pathol. 2004, 202, 157-163. [CrossRef]

119. Harrison, A.G.; Lin, T.; Wang, P. Mechanisms of SARS-CoV-2 transmission and pathogenesis. Trends Immunol. 2020, 41, 1100-1115. [CrossRef]

120. Hikmet, F.; Méar, L.; Edvinsson, Å.; Micke, P.; Uhlén, M.; Lindskog, C. The protein expression profile of ACE2 in human tissues. Mol. Syst. Biol. 2020, 16, e9610. [CrossRef]

121. Hulswit, R.J.G.; Lang, Y.; Bakkers, M.J.G.; Li, W.; Li, Z.; Schouten, A.; Ophorst, B.; Van Kuppeveld, F.J.M.; Boons, G.-J.; Bosch, B.-J.; et al. Human coronaviruses OC43 and HKU1 bind to 9-O-acetylated sialic acids via a conserved receptor-binding site in spike protein domain A. Proc. Natl. Acad. Sci. USA 2019, 116, 2681-2690. [CrossRef]

122. Chan, C.M.; Lau, S.K.P.; Woo, P.C.Y.; Tse, H.; Zheng, B.-J.; Chen, L.; Huang, J.-D.; Yuen, K.-Y. Identification of major histocompatibility complex class I C molecule as an attachment factor that facilitates coronavirus HKU1 spike-mediated infection. J. Virol. 2009, 83, 1026-1035. [CrossRef]

123. Szczepanski, A.; Owczarek, K.; Bzowska, M.; Gula, K.; Drebot, I.; Ochman, M.; Maksym, B.; Rajfur, Z.; Mitchell, J.; Pyrc, K. Canine respiratory coronavirus, bovine coronavirus, and human coronavirus OC43: Receptors and attachment factors. Viruses 2019, 11, 328. [CrossRef]

124. Marzi, A.; Gramberg, T.; Simmons, G.; Möller, P.; Rennekamp, A.J.; Krumbiegel, M.; Geier, M.; Eisemann, J.; Turza, N.; Saunier, B.; et al. DC-SIGN and DC-SIGNR interact with the glycoprotein of marburg virus and the $S$ protein of severe acute respiratory syndrome coronavirus. J. Virol. 2004, 78, 12090-12095. [CrossRef] [PubMed]

125. Chan, C.-M.; Chu, H.; Wang, Y.; Wong, B.H.-Y.; Zhao, X.; Zhou, J.; Yang, D.; Leung, S.P.; Chan, J.F.-W.; Yeung, M.-L.; et al. Carcinoembryonic antigen-related cell adhesion molecule 5 is an important surface attachment factor that facilitates entry of middle east respiratory syndrome coronavirus. J. Virol. 2016, 90, 9114-9127. [CrossRef]

126. Earnest, J.T.; Hantak, M.P.; Li, K.; McCray, P.B.; Perlman, S.; Gallagher, T. The tetraspanin CD9 facilitates MERS-coronavirus entry by scaffolding host cell receptors and proteases. PLoS Pathog 2017, 13, e1006546. [CrossRef] [PubMed]

127. Chu, H.; Chan, C.-M.; Zhang, X.; Wang, Y.; Yuan, S.; Zhou, J.; Au-Yeung, R.K.-H.; Sze, K.-H.; Yang, D.; Shuai, H.; et al. Middle east respiratory syndrome coronavirus and bat coronavirus HKU9 both can utilize GRP78 for attachment onto host cells. J. Biol. Chem. 2018, 293, 11709-11726. [CrossRef] [PubMed]

128. Chu, H.; Hu, B.; Huang, X.; Chai, Y.; Zhou, D.; Wang, Y.; Shuai, H.; Yang, D.; Hou, Y.; Zhang, X.; et al. Host and viral determinants for efficient SARS-CoV-2 infection of the human lung. Nat. Commun. 2021, 12, 134. [CrossRef] [PubMed]

129. Shang, J.; Wan, Y.; Luo, C.; Ye, G.; Geng, Q.; Auerbach, A.; Li, F. Cell entry mechanisms of SARS-CoV-2. Proc. Natl. Acad. Sci. USA 2020, 117, 11727-11734. [CrossRef] [PubMed]

130. Mycroft-West, C.J.; Su, D.; Pagani, I.; Rudd, T.R.; Elli, S.; Gandhi, N.S.; Guimond, S.E.; Miller, G.J.; Meneghetti, M.C.Z.; Nader, H.B.; et al. Heparin inhibits cellular invasion by SARS-CoV-2: Structural dependence of the interaction of the spike S1 receptor-binding domain with heparin. Thromb. Haemost. 2020, 120, 1700-1715.

131. Kalra, R.S.; Kandimalla, R. Engaging the spikes: Heparan sulfate facilitates SARS-CoV-2 spike protein binding to ACE2 and potentiates viral infection. Signal Transduct. Target. Ther. 2021, 6, 39. [CrossRef]

132. Yu, M.; Zhang, T.; Zhang, W.; Sun, Q.; Li, H.; Li, J. Elucidating the interactions between heparin/heparan sulfate and SARS-CoV2-related proteins-An important strategy for developing novel therapeutics for the COVID-19 pandemic. Front. Mol. Biosci. 2021, 7, 628551. [CrossRef] [PubMed]

133. Liu, L.; Chopra, P.; Li, X.; Wolfert, M.A.; Tompkins, S.M.; Boons, G.-J. SARS-CoV-2 spike protein binds heparan sulfate in a lengthand sequence-dependent manner. bioRxiv 2020, 2. [CrossRef] 
134. Kim, S.Y.; Jin, W.; Sood, A.; Montgomery, D.W.; Grant, O.C.; Fuster, M.M.; Fu, L.; Dordick, J.S.; Woods, R.J.; Zhang, F.; et al. Characterization of heparin and severe acute respiratory syndrome-related coronavirus 2 (SARS-CoV-2) spike glycoprotein binding interactions. Antiviral Res. 2020, 181, 104873. [CrossRef]

135. Coutard, B.; Valle, C.; Lamballerie, X.D.; Canard, B.; Seidah, N.G.; Decroly, E. The spike glycoprotein of the new coronavirus 2019-nCoV contains a furin-like cleavage site absent in CoV of the same clade. Antiviral Res. 2020, 176, 104742. [CrossRef]

136. Hoffmann, M.; Kleine-Weber, H.; Schroeder, S.; Krüger, N.; Herrler, T.; Erichsen, S.; Schiergens, T.S.; Herrler, G.; Wu, N.-H.; Nitsche, A.; et al. SARS-CoV-2 Cell entry depends on ACE2 and TMPRSS2 and is blocked by a clinically proven protease inhibitor. Cell 2020, 181, 271-280.e8. [CrossRef]

137. Xia, X. Domains and functions of spike protein in SARS-Cov-2 in the context of vaccine design. Viruses 2021, 13, 109. [CrossRef] [PubMed]

138. Novinec, M.; Lenarčič, B.; Turk, B. Cysteine cathepsin activity regulation by glycosaminoglycans. Biomed. Res. Int. 2014, 2014, 1-9. [CrossRef]

139. Jeon, S.; Ko, M.; Lee, J.; Choi, I.; Byun, S.Y.; Park, S.; Shum, D.; Kim, S. Identification of antiviral drug candidates against SARS-CoV-2 from FDA-approved drugs. Antimicrob. Agents Chemother. 2020, 64, e00819-e00820. [CrossRef] [PubMed]

140. Zhang, Q.; Xu, Y.; Lee, J.; Jarnik, M.; Wu, X.; Bonifacino, J.S.; Shen, J.; Ye, Y. A myosin-7B-dependent endocytosis pathway mediates cellular entry of $\alpha$-synuclein fibrils and polycation-bearing cargos. Proc. Natl. Acad. Sci. USA 2020, 117, 10865-10875. [CrossRef]

141. Wang, W.; Xu, Y.; Gao, R.; Lu, R.; Han, K.; Wu, G.; Tan, W. Detection of SARS-CoV-2 in different types of clinical specimens. JAMA 2020, 323, 1843-1844. [CrossRef]

142. Hui, K.P.Y.; Cheung, M.-C.; Perera, R.A.P.M.; Ng, K.-C.; Bui, C.H.T.; Ho, J.C.W.; Ng, M.M.T.; Kuok, D.I.T.; Shih, K.C.; Tsao, S.-W.; et al. Tropism, replication competence, and innate immune responses of the coronavirus SARS-CoV-2 in human respiratory tract and conjunctiva: An analysis in ex-vivo and in-vitro cultures. Lancet Respir. Med. 2020, 8, 687-695. [CrossRef]

143. Puelles, V.G.; Lütgehetmann, M.; Lindenmeyer, M.T.; Sperhake, J.P.; Wong, M.N.; Allweiss, L.; Chilla, S.; Heinemann, A.; Wanner, N.; Liu, S.; et al. Multiorgan and renal tropism of SARS-CoV-2. N. Engl. J. Med. 2020, 383, 590-592. [CrossRef]

144. Xiao, F.; Tang, M.; Zheng, X.; Liu, Y.; Li, X.; Shan, H. Evidence for gastrointestinal infection of SARS-CoV-2. Gastroenterology 2020, 158, 1831-1833.e3. [CrossRef] [PubMed]

145. Bwire, G.M.; Majigo, M.V.; Njiro, B.J.; Mawazo, A. Detection profile of SARS-CoV-2 using RT-PCR in different types of clinical specimens: A systematic review and meta-analysis. J. Med. Virol. 2021, 93, 719-725. [CrossRef] [PubMed]

146. Haeger, S.M.; Yang, Y.; Schmidt, E.P. Heparan sulfate in the developing, healthy, and injured lung. Am. J. Respir. Cell Mol. Biol. 2016, 55, 5-11. [CrossRef]

147. Leiner, K.A.; Newman, D.; Li, C.-M.; Walsh, E.; Khosla, J.; Sannes, P.L. Heparin and fibroblast growth factors affect surfactant protein gene expression in type II cells. Am. J. Respir. Cell Mol. Biol. 2006, 35, 611-618. [CrossRef]

148. Zhang, H.; Newman, D.R.; Sannes, P.L. HSULF-1 inhibits ERK and AKT signaling and decreases cell viability in vitro in human lung epithelial cells. Respir. Res. 2012, 13, 69. [CrossRef]

149. Yang, Y.; Schmidt, E.P. The endothelial glycocalyx. Tissue Barriers 2013, 1, e23494. [CrossRef]

150. Nägele, M.P.; Haubner, B.; Tanner, F.C.; Ruschitzka, F.; Flammer, A.J. Endothelial dysfunction in COVID-19: Current findings and therapeutic implications. Atherosclerosis 2020, 314, 58-62. [CrossRef]

151. Giannis, D.; Ziogas, I.A.; Gianni, P. Coagulation disorders in coronavirus infected patients: COVID-19, SARS-CoV-1, MERS-CoV and lessons from the past. J. Clin. Virol. 2020, 127, 104362. [CrossRef] [PubMed]

152. Varga, Z.; Flammer, A.J.; Steiger, P.; Haberecker, M.; Andermatt, R.; Zinkernagel, A.S.; Mehra, M.R.; Schuepbach, R.A.; Ruschitzka, F.; Moch, H. Endothelial cell infection and endotheliitis in COVID-19. Lancet 2020, 395, 1417-1418. [CrossRef]

153. Humbert, M.; Guignabert, C.; Bonnet, S.; Dorfmüller, P.; Klinger, J.R.; Nicolls, M.R.; Olschewski, A.J.; Pullamsetti, S.S.; Schermuly, R.T.; Stenmark, K.R.; et al. Pathology and pathobiology of pulmonary hypertension: State of the art and research perspectives. Eur. Respir. J. 2019, 53, 1801887. [CrossRef] [PubMed]

154. Ackermann, M.; Verleden, S.E.; Kuehnel, M.; Haverich, A.; Welte, T.; Laenger, F.; Vanstapel, A.; Werlein, C.; Stark, H.; Tzankov, A.; et al. Pulmonary vascular endothelialitis, thrombosis, and angiogenesis in covid-19. N. Engl. J. Med. 2020, 383, 120-128. [CrossRef] [PubMed]

155. Turco, S.D.; Vianello, A.; Ragusa, R.; Caselli, C.; Basta, G. COVID-19 and cardiovascular consequences: Is the endothelial dysfunction the hardest challenge? Thromb. Res. 2020, 196, 143-151. [CrossRef]

156. Hamming, I.; Timens, W.; Bulthuis, M.; Lely, A.; Navis, G.; Van Goor, H. Tissue distribution of ACE2 protein, the functional receptor for SARS coronavirus. A first step in understanding SARS pathogenesis. J. Pathol. 2004, 203, 631-637. [CrossRef]

157. Li, M.-Y.; Li, L.; Zhang, Y.; Wang, X.-S. Expression of the SARS-CoV-2 cell receptor gene ACE2 in a wide variety of human tissues. Infect. Dis. Poverty 2020, 9, 45. [CrossRef]

158. Yamaoka-Tojo, M. Vascular endothelial glycocalyx damage in COVID-19. Int. J. Mol. Sci. 2020, 21, 9712. [CrossRef]

159. Curry, F.E. Layer upon layer: The functional consequences of disrupting the glycocalyx-endothelial barrier in vivo and in vitro. Cardiovasc. Res. 2017, 113, 559-561. [CrossRef] [PubMed] 
160. Bar, A.; Targosz-Korecka, M.; Suraj, J.; Proniewski, B.; Jasztal, A.; Marczyk, B.; Sternak, M.; Przybyło, M.; Kurpińska, A.; Walczak, M.; et al. Degradation of glycocalyx and multiple manifestations of endothelial dysfunction coincide in the early phase of endothelial dysfunction before atherosclerotic plaque development in apolipoprotein E/low-density lipoprotein receptordeficient mice. J. Am. Heart Assoc. 2019, 8, e011171. [CrossRef]

161. Miranda, C.H.; Carvalho Borges, M.D.; Schmidt, A.; Marin-Neto, J.A.; Pazin-Filho, A. Evaluation of the endothelial glycocalyx damage in patients with acute coronary syndrome. Atherosclerosis 2016, 247, 184-188. [CrossRef]

162. Ostrowski, S.R.; Gaïni, S.; Pedersen, C.; Johansson, P.I. Sympathoadrenal activation and endothelial damage in patients with varying degrees of acute infectious disease: An observational study. J. Crit. Care 2015, 30, 90-96. [CrossRef]

163. Becker, B.F.; Jacob, M.; Leipert, S.; Salmon, A.H.J.; Chappell, D. Degradation of the endothelial glycocalyx in clinical settings: Searching for the sheddases. Br. J. Clin. Pharmacol. 2015, 80, 389-402. [CrossRef] [PubMed]

164. Padberg, J.-S.; Wiesinger, A.; Marco, G.S.D.; Reuter, S.; Grabner, A.; Kentrup, D.; Lukasz, A.; Oberleithner, H.; Pavenstädt, H.; Brand, M.; et al. Damage of the endothelial glycocalyx in chronic kidney disease. Atherosclerosis 2014, 234, 335-343. [CrossRef]

165. Neves, F.M.D.O.; Meneses, G.C.; Sousa, N.E.A.; Parahyba, M.C.; Martins, A.M.C.; Libório, A.B. Syndecan-1 in acute decompensated heart failure-Association with renal function and mortality. Circ. J. 2015, 79, 1511-1519. [CrossRef] [PubMed]

166. Nussbaum, C.; Heringa, A.C.F.; Mormanova, Z.; Puchwein-Schwepcke, A.F.; Bechtold-Dalla Pozza, S.; Genzel-Boroviczény, O. Early microvascular changes with loss of the glycocalyx in children with type 1 diabetes. J. Pediatr. 2014, 164, 584-589.e1. [CrossRef] [PubMed]

167. Bruegger, D.; Brettner, F.; Rossberg, I.; Nussbaum, C.; Kowalski, C.; Januszewska, K.; Becker, B.F.; Chappell, D. Acute degradation of the endothelial glycocalyx in infants undergoing cardiac surgical procedures. Ann. Thorac. Surg. 2015, 99, 926-931. [CrossRef] [PubMed]

168. Çekiç, C.; Kırc1, A.; Vatansever, S.; Aslan, F.; Yılmaz, H.E.; Alper, E.; Arabul, M.; Sarıtaş Yüksel, E.; Ünsal, B. Serum syndecan-1 levels and its relationship to disease activity in patients with Crohn's disease. Gastroenterol. Res. Pract. 2015, 2015, 1-6. [CrossRef]

169. Schmidt, E.P.; Li, G.; Li, L.; Fu, L.; Yang, Y.; Overdier, K.H.; Douglas, I.S.; Linhardt, R.J. The circulating glycosaminoglycan signature of respiratory failure in critically ill adults. J. Biol. Chem. 2014, 289, 8194-8202. [CrossRef] [PubMed]

170. Ghadiali, R.S.; Guimond, S.E.; Turnbull, J.E.; Pisconti, A. Dynamic changes in heparan sulfate during muscle differentiation and ageing regulate myoblast cell fate and FGF2 signalling. Matrix Biol. 2017, 59, 54-68. [CrossRef]

171. Yamada, T.; Kerever, A.; Yoshimura, Y.; Suzuki, Y.; Nonaka, R.; Higashi, K.; Toida, T.; Mercier, F.; Arikawa-Hirasawa, E. Heparan sulfate alterations in extracellular matrix structures and fibroblast growth factor-2 signaling impairment in the aged neurogenic niche. J. Neurochem. 2017, 142, 534-544. [CrossRef]

172. Scully, E.P.; Haverfield, J.; Ursin, R.L.; Tannenbaum, C.; Klein, S.L. Considering how biological sex impacts immune responses and COVID-19 outcomes. Nat. Rev. Immunol. 2020, 20, 442-447. [CrossRef]

173. Zhou, F.; Yu, T.; Du, R.; Fan, G.; Liu, Y.; Liu, Z.; Xiang, J.; Wang, Y.; Song, B.; Gu, X.; et al. Clinical course and risk factors for mortality of adult inpatients with COVID-19 in Wuhan, China: A retrospective cohort study. Lancet 2020, 395, 1054-1062. [CrossRef]

174. Pasquale, V.D.; Sarogni, P.; Pistorio, V.; Cerulo, G.; Paladino, S.; Pavone, L.M. Targeting heparan sulfate proteoglycans as a novel therapeutic strategy for mucopolysaccharidoses. Mol. Ther. Methods Clin. Dev. 2018, 10, 8-16. [CrossRef] [PubMed]

175. Tavassoly, O.; Safavi, F.; Tavassoly, I. Heparin-binding peptides as novel therapies to stop SARS-CoV-2 cellular entry and infection. Mol. Pharmacol. 2020, 98, 612-619. [CrossRef] [PubMed]

176. Al-Horani, R.A.; Kar, S.; Aliter, K.F. Potential anti-COVID-19 therapeutics that block the early stage of the viral life cycle: Structures, mechanisms, and clinical trials. Int. J. Mol. Sci. 2020, 21, 5224. [CrossRef] [PubMed]

177. Glebov, O.O. Understanding SARS-CoV-2 endocytosis for COVID-19 drug repurposing. FEBS J. 2020, 287, 3664-3671. [CrossRef]

178. Tiwari, V.; Beer, J.C.; Sankaranarayanan, N.V.; Swanson-Mungerson, M.; Desai, U.R. Discovering small-molecule therapeutics against SARS-CoV-2. Drug Discov. Today 2020, 25, 1535-1544.

179. Tandon, R.; Sharp, J.S.; Zhang, F.; Pomin, V.H.; Ashpole, N.M.; Mitra, D.; McCandless, M.G.; Jin, W.; Liu, H.; Sharma, P.; et al. Effective inhibition of SARS-CoV-2 entry by heparin and enoxaparin derivatives. J. Virol. 2020, 95, e01987-e02020. [CrossRef]

180. Hippensteel, J.A.; LaRiviere, W.B.; Colbert, J.F.; Langouët-Astrié, C.J.; Schmidt, E.P. Heparin as a therapy for COVID-19: Current evidence and future possibilities. Am. J. Physiol. Cell. Mol. Physiol. 2020, 319, L211-L217. [CrossRef] [PubMed]

181. Conzelmann, C.; Müller, J.A.; Perkhofer, L.; Sparrer, K.M.; Zelikin, A.N.; Münch, J.; Kleger, A. Inhaled and systemic heparin as a repurposed direct antiviral drug for prevention and treatment of COVID-19. Clin. Med. 2020, 20, e218-e221. [CrossRef]

182. Thachil, J. The versatile heparin in COVID-19. J. Thromb. Haemost. 2020, 18, 1020-1022. [CrossRef]

183. Buijsers, B.; Yanginlar, C.; Maciej-Hulme, M.L.; Mast, Q.D.; Van der Vlag, J. Beneficial non-anticoagulant mechanisms underlying heparin treatment of COVID-19 patients. EBioMedicine 2020, 59, 102969. [CrossRef] [PubMed]

184. Dogra, P.; Martin, E.B.; Williams, A.; Richardson, R.L.; Foster, J.S.; Hackenback, N.; Kennel, S.J.; Sparer, T.E.; Wall, J.S. Novel heparan sulfate-binding peptides for blocking herpesvirus entry. PLoS ONE 2015, 10, e0126239. [CrossRef]

185. Pitt, E.A.; Dogra, P.; Patel, R.S.; Williams, A.; Wall, J.S.; Sparer, T.E. The D-form of a novel heparan binding peptide decreases cytomegalovirus infection in vivo and in vitro. Antiviral Res. 2016, 135, 15-23. [CrossRef]

186. Knittel, D.; Savatier, A.; Upert, G.; Lortat-Jacob, H.; Léonetti, M. Acidosis increases MHC class II-Restricted presentation of a protein endowed with a pH-dependent heparan sulfate-binding ability. J. Immunol. 2015, 194, 3601-3611. [CrossRef] [PubMed] 
187. Kakimoto, S.; Hamada, T.; Komatsu, Y.; Takagi, M.; Tanabe, T.; Azuma, H.; Shinkai, S.; Nagasaki, T. The conjugation of diphtheria toxin $\mathrm{T}$ domain to poly(ethylenimine) based vectors for enhanced endosomal escape during gene transfection. Biomaterials 2009, 30, 402-408. [CrossRef]

188. Wall, J.S.; Stuckey, A.; Martin, E.B.; Richey, T.; Williams, A.; Wooliver, D.C.; Macy, S.; Foster, J.S.; Whittle, B.; Geldrich, R.; et al. Preliminary phase 1 data on the safety and efficacy of a novel PET radiotracer, ${ }^{124} \mathrm{I}-\mathrm{p} 5+14$, for imaging systemic amyloidosis. Blood 2019, 134, 3034. [CrossRef]

189. Stuckey, A.; Martin, E.; Powell, D.; Fu, Y.; Besozzi, M.; Hall, S.; Kennel, S.; Wall, J. Time resolved biodistribution of peptide ${ }^{124} \mathrm{I}-\mathrm{p} 5+14$ in patients with systemic AL amyloidosis. J. Nucl. Med. 2020, 61, 3127.

190. Wang, Y.; Wang, P.; Wang, H.; Luo, Y.; Wan, L.; Jiang, M.; Chu, Y. Lactoferrin for the treatment of COVID-19 (Review). Exp. Ther. Med. 2020, 20, 1. [CrossRef]

191. Chang, R.; Ng, T.B.; Sun, W.-Z. Lactoferrin as potential preventative and adjunct treatment for COVID-19. Int. J. Antimicrob. Agents 2020, 56, 106118. [CrossRef]

192. Hu, Y.; Meng, X.; Zhang, F.; Xiang, Y.; Wang, J. The in vitro antiviral activity of lactoferrin against common human coronaviruses and SARS-CoV-2 is mediated by targeting the heparan sulfate co-receptor. Emerg. Microbes Infect. 2021, 10, 317-330. [CrossRef]

193. Andersen, J.H.; Jenssen, H.; Sandvik, K.; Gutteberg, T.J. Anti-HSV activity of lactoferrin and lactoferricin is dependent on the presence of heparan sulphate at the cell surface. J. Med. Virol. 2004, 74, 262-271. [CrossRef] [PubMed]

194. Lang, J.; Yang, N.; Deng, J.; Liu, K.; Yang, P.; Zhang, G.; Jiang, C. Inhibition of SARS pseudovirus cell entry by lactoferrin binding to heparan sulfate proteoglycans. PLoS ONE 2011, 6, e23710. [CrossRef]

195. Nozaki, A.; Ikeda, M.; Naganuma, A.; Nakamura, T.; Inudoh, M.; Tanaka, K.; Kato, N. Identification of a lactoferrin-derived peptide possessing binding activity to hepatitis C virus E2 envelope protein. J. Biol. Chem. 2003, 278, 10162-10173. [CrossRef] [PubMed]

196. Kell, D.B.; Heyden, E.L.; Pretorius, E. The biology of lactoferrin, an iron-binding protein that can help defend against viruses and bacteria. Front. Immunol. 2020, 11, 1221. [CrossRef]

197. Mazzon, M.; Ortega-Prieto, A.; Imrie, D.; Luft, C.; Hess, L.; Czieso, S.; Grove, J.; Skelton, J.; Farleigh, L.; Bugert, J.; et al. Identification of broad-spectrum antiviral compounds by targeting viral entry. Viruses 2019, 11, 176. [CrossRef]

198. Zhong, J.-H.; Li, H.; Li, L.-Q.; You, X.-M.; Zhang, Y.; Zhao, Y.-N.; Liu, J.-Y.; Xiang, B.-D.; Wu, G.-B. Adjuvant therapy options following curative treatment of hepatocellular carcinoma: A systematic review of randomized trials. Eur. J. Surg. Oncol. 2012, 38, 286-295. [CrossRef]

199. Khanna, M.; Ranasinghe, C.; Jackson, R.; Parish, C.R. Heparan sulfate as a receptor for poxvirus infections and as a target for antiviral agents. J. Gen. Virol. 2017, 98, 2556-2568. [CrossRef] [PubMed]

200. Ekblad, M.; Adamiak, B.; Bergstrom, T.; Johnstone, K.D.; Karoli, T.; Liu, L.; Ferro, V.; Trybala, E. A highly lipophilic sulfated tetrasaccharide glycoside related to muparfostat (PI-88) exhibits virucidal activity against herpes simplex virus. Antiviral Res. 2010, 86, 196-203. [CrossRef] [PubMed]

201. Lee, E.; Pavy, M.; Young, N.; Freeman, C.; Lobigs, M. Antiviral effect of the heparan sulfate mimetic, PI-88, against dengue and encephalitic flaviviruses. Antiviral Res. 2006, 69, 31-38. [CrossRef]

202. Thakkar, N.; Yadavalli, T.; Jaishankar, D.; Shukla, D. Emerging roles of heparanase in viral pathogenesis. Pathogens 2017, 6, 43. [CrossRef]

203. Egorova, A.; Bogner, E.; Novoselova, E.; Zorn, K.M.; Ekins, S.; Makarov, V. Dispirotripiperazine-core compounds, their biological activity with a focus on broad antiviral property, and perspectives in drug design (mini-review). Eur. J. Med. Chem. 2021, 211, 113014. [CrossRef] [PubMed]

204. Pala, D.; Rivara, S.; Mor, M.; Milazzo, F.M.; Roscilli, G.; Pavoni, E.; Giannini, G. Kinetic analysis and molecular modeling of the inhibition mechanism of roneparstat (SST0001) on human heparanase. Glycobiology 2016, 26, 640-654. [CrossRef]

205. Salata, C.; Calistri, A.; Parolin, C.; Baritussio, A.; Palù, G. Antiviral activity of cationic amphiphilic drugs. Expert Rev. Anti. Infect. Ther. 2017, 15, 483-492. [CrossRef] [PubMed]

206. Salgado-Benvindo, C.; Thaler, M.; Tas, A.; Ogando, N.S.; Bredenbeek, P.J.; Ninaber, D.K.; Wang, Y.; Hiemstra, P.S.; Snijder, E.J.; Van Hemert, M.J. Suramin inhibits SARS-CoV-2 infection in cell culture by interfering with early steps of the replication cycle. Antimicrob. Agents Chemother. 2020, 64, e00900-e01020. [CrossRef] [PubMed]

207. Garson, J.A.; Lubach, D.; Passas, J.; Whitby, K.; Grant, P.R. Suramin blocks hepatitis C binding to human hepatoma cells in vitro. J. Med. Virol. 1999, 57, 238-242. [CrossRef]

208. Aguilar, J.S.; Rice, M.; Wagner, E.K. The polysulfonated compound suramin blocks adsorption and lateral difusion of herpes simplex virus type-1 in vero cells. Virology 1999, 258, 141-151. [CrossRef] [PubMed]

209. Albulescu, I.C.; Kovacikova, K.; Tas, A.; Snijder, E.J.; Van Hemert, M.J. Suramin inhibits Zika virus replication by interfering with virus attachment and release of infectious particles. Antiviral Res. 2017, 143, 230-236. [CrossRef]

210. Ekins, S.; Madrid, P.B. Tilorone, a broad-spectrum antiviral for emerging viruses. Antimicrob. Agents Chemother. 2020, 64, e00440-e00520. [CrossRef]

211. Barrett, C.D.; Moore, H.B.; Yaffe, M.B.; Moore, E.E. ISTH interim guidance on recognition and management of coagulopathy in COVID-19: A comment. J. Thromb. Haemost. 2020, 18, 2060-2063. [CrossRef] 
212. Yang, Y.; Haeger, S.M.; Suflita, M.A.; Zhang, F.; Dailey, K.L.; Colbert, J.F.; Ford, J.A.; Picon, M.A.; Stearman, R.S.; Lin, L.; et al. Fibroblast growth factor signaling mediates pulmonary endothelial glycocalyx reconstitution. Am. J. Respir. Cell Mol. Biol. 2017, 56, 727-737. [CrossRef]

213. Zhang, Y.; Haeger, S.M.; Yang, Y.; Dailey, K.L.; Ford, J.A.; Schmidt, E.P. Circulating heparan sulfate fragments attenuate histone-induced lung injury independently of histone binding. Shock 2017, 48, 666-673. [CrossRef]

214. Hippensteel, J.A.; Anderson, B.J.; Orfila, J.E.; McMurtry, S.A.; Dietz, R.M.; Su, G.; Ford, J.A.; Oshima, K.; Yang, Y.; Zhang, F.; et al. Circulating heparan sulfate fragments mediate septic cognitive dysfunction. J. Clin. Investig. 2019, 129, 1779-1784. [CrossRef] [PubMed]

215. LaRivière, W.B.; Liao, S.; McMurtry, S.A.; Oshima, K.; Han, X.; Zhang, F.; Yan, S.; Haeger, S.M.; Ransom, M.; Bastarache, J.A.; et al. Alveolar heparan sulfate shedding impedes recovery from bleomycin-induced lung injury. Am. J. Physiol. Cell. Mol. Physiol. 2020, 318, L1198-L1210. [CrossRef] [PubMed]

216. Chua, J.S.; Kuberan, B. Synthetic xylosides: Probing the glycosaminoglycan biosynthetic machinery for biomedical applications. Acc. Chem. Res. 2017, 50, 2693-2705. [CrossRef] [PubMed]

217. Moskot, M.; Jakóbkiewicz-Banecka, J.; Kloska, A.; Smolińska, E.; Mozolewski, P.; Malinowska, M.; Rychłowski, M.; Banecki, B.; Węgrzyn, G.; Gabig-Cimińska, M. Modulation of expression of genes involved in glycosaminoglycan metabolism and lysosome biogenesis by flavonoids. Sci. Rep. 2015, 5, 9378. [CrossRef] [PubMed]

218. Pasquale, V.D.; Pezone, A.; Sarogni, P.; Tramontano, A.; Schiattarella, G.G.; Avvedimento, V.E.; Paladino, S.; Pavone, L.M. EGFR activation triggers cellular hypertrophy and lysosomal disease in NAGLU-depleted cardiomyoblasts, mimicking the hallmarks of mucopolysaccharidosis IIIB. Cell Death Dis. 2018, 9, 40. [CrossRef]

219. Xiong, P.; Wang, R.; Zhang, X.; DeLa Torre, E.; Leon, F.; Zhang, Q.; Zheng, S.; Wang, G.; Chen, Q.-H. Design, synthesis, and evaluation of genistein analogues as anti-cancer agents. Anticancer. Agents Med. Chem. 2015, 15, 1197-1203. [CrossRef]

220. López, T.; López, S.; Arias, C.F. The tyrosine kinase inhibitor genistein induces the detachment of rotavirus particles from the cell surface. Virus Res. 2015, 210, 141-148. [CrossRef] [PubMed]

221. Agelidis, A.; Shukla, D. Heparanase, heparan sulfate and viral infection. Adv. Exp. Med. Biol. 2020, 1221, 759-770.

222. Koganti, R.; Suryawanshi, R.; Shukla, D. Heparanase, cell signaling, and viral infections. Cell. Mol. Life Sci. 2020, 77, 5059-5077. [CrossRef] [PubMed]

223. Deakin, J.A.; Blaum, B.S.; Gallagher, J.T.; Uhrín, D.; Lyon, M. The binding properties of minimal oligosaccharides reveal a common heparan sulfate/dermatan sulfate-binding site in hepatocyte growth factor/scatter factor that can accommodate a wide variety of sulfation patterns. J. Biol. Chem. 2009, 284, 6311-6321. [CrossRef] [PubMed]

224. Hondermarck, H.; Bartlett, N.W.; Nurcombe, V. The role of growth factor receptors in viral infections: An opportunity for drug repurposing against emerging viral diseases such as COVID-19? FASEB BioAdv. 2020, 2, 296-303. [CrossRef] [PubMed]

225. Hudák, A.; Letoha, A.; Szilák, L.; Letoha, T. Contribution of syndecans to the cellular entry of SARS-CoV-2. Int. J. Mol. Sci. 2021, 22, 5336. [CrossRef] [PubMed]

226. Farrugia, B.L.; Lord, M.S.; Melrose, J.; Whitelock, J.M. The role of heparan sulfate in inflammation, and the development of biomimetics as anti-inflammatory strategies. J. Histochem. Cytochem. 2018, 66, 321-336. [CrossRef]

227. Morla, S. Glycosaminoglycans and glycosaminoglycan mimetics in cancer and Inflammation. Int. J. Mol. Sci. 2019, 20, 1963. [CrossRef]

228. D'Alonzo, D.; Fenza, M.D.; Pavone, V. COVID-19 and pneumonia: A role for the uPA/uPAR system. Drug Discov. Today 2020, 25, 1528-1534. [CrossRef] 